\title{
PROPOSAL FOR AN ITALIAN FAMILY MEDIATION CLINIC
}

\author{
Andrea Gallinucci-Martinez, Columbia Law School, United States of America
}

\section{Acknowledgements}

I am truly blessed to have an amazing family that always supports me, and I hope this work can inform programs that empower families to reinforce positive communication and productive dialogue. I want to dedicate this work to my wife Tanya, my mother Cinzia, my father Giancarlo and my grandmother Iolanda. I also want to thank Professors Carol Liebman, Alexandra Carter and Lecturer in Law Shawn Watts of Columbia Law School and Professors Monica Lugato, Emanuele Odorisio and Angelo Rinella of Libera Università Maria SS. Assunta for their invaluable contributions to this research and their constant support and encouragement. Finally, my gratitude goes to all the administrative assistants of the clinical programs at Columbia Law School. I welcome feedback on this article and/or general ideas on the topics discussed. Please feel free to contact me at ag3745@columbia.edu.

\section{Introduction}

Before joining Columbia Law School's LL.M. program, my understanding of clinical legal education was very limited. Being the product of an Italian legal education, I was not even sure of what exactly a law school clinic was. Then, I took my first steps into this fascinating field with the help of Professor Alexandra Carter and Lecturer-InLaw Shawn Watts. I became impressed by the learning experience provided by the mediation clinic, and came to realise that clinical teaching could be incredibly beneficial 
for law students all over the world and within each and every academic environment.

For these reasons, I decided to focus my research on creating a framework for the introduction of a mediation clinic in Italy, via collaboration with Libera Università Maria SS. Assunta (“LUMSA”) in Rome. ${ }^{1}$

In order to properly consider how a mediation clinic could be implemented in LUMSA, I had to learn about clinical education and how it developed. For this reason, section A of this paper discusses the historical evolution of clinical legal programs in the United States, the homeland of clinical legal education. Next, I discuss the current framework of Italian legal clinics, focusing on its American heritage and associated nuances.

After understanding the evolution of clinical legal education, I needed to understand how it is currently implemented, and how this model could be adapted in other settings. Section B considers why mediation would be particularly suitable for the creation of an Italian legal clinic, given the recent incentives created by the European

\footnotetext{
1 For similar research in different contexts, see Schrag P., Constructing a Clinic, 3 Clinical Law Review 175 (1996); Broadhead P., A Model Program for Establishing a Criminal Appeals Clinic at Your School More Bang for the Buck, 75 Mississippi Law Journal 671 (2006); Jessup G., Symbiotic Relations: Clinical Methodology-Fostering New Paradigms in African Legal Education, 8 Clinical Law Review 377 (2002); Rosenbaum S., The Legal Clinic Is More Than a Sign on the Door: Transforming Law School Education in Revolutionary Egypt, 5 Berkeley Journal Middle East \& Islamic Law 39 (2012); Wilson R., Three Law School Clinics in Chile, 1970-2000: Innovation, Resistance and Conformity in the Global South, 8 Clinical Law Review 801 (2002); Zielińska E. et al., The Legal Clinic: The Idea, Organization, Methodology, The Legal Clinics Foundation - Warsaw (2005); Qafisheh M., Reforming Legal Education through Clinical Pedagogy: Legal Education in Palestine, 4(2) Asian Journal of Legal Education 146 (2017).
} 
legislature to strengthen alternative dispute resolution. Then, taking advantage of the institutional knowledge of Professors Carol Liebman and Alexandra Carter, I describe the evolution of the Columbia Law School Mediation Clinic, from its beginning to the recent creation of an advanced clinic model. Finally, I describe how these insights can inform laying the foundations for an Italian mediation clinic at LUMSA.

Section C lays out baseline considerations and recommendations for creating a family mediation clinic at LUMSA. To this end, I analyse three different approaches to family and community mediation previously adopted in the context of clinical legal education: facilitative mediation, transformative mediation, and peacemaking circle. Then, I propose a model tailored to the cultural, legal, and educational needs of LUMSA and of the families the clinic hopes to serve. Finally, I provide sources and materials for the proposed curriculum, including a sample role-play that I created.

\section{A. Clinical Legal Education}

\section{The Development of Clinical Legal Education in the United States}

The evolution of clinical legal education in the United States starts in 1933 in New Haven, with the publication of a law review article called "Why Not a Clinical LawyerSchool?" ${ }^{2}$ by Professor Jerome Frank, who referred to the law school curriculum as

\footnotetext{
$2 \quad$ Frank J., Why Not a Clinical Lawyer-School?, 81 University of Pennsylvania Law Review 907 (1933). See, also, Frank J., What Constitutes a Good Legal Education?, 19 American Bar Association Journal 723
} 
Reviewed Article - Teaching and Learning in Clinic

inadequate and unreasonably abstract, because of the absence of any apprenticeship at

all. ${ }^{3}$ The article proposed that law schools should follow the example of medical schools and open clinics, staffed by faculty with practical experience that would offer legal services for a nominal fee. ${ }^{4}$ This position was later reaffirmed by Karl Llewellyn, Professor at Columbia Law School, who did not believe, as Frank seemed to, in the complete substitution of theoretical instruction, but strongly advanced the idea that theoretical studies should be accompanied by practical complements. ${ }^{5}$ Despite having different views on the extent to which practical activities should be incorporated in the law school curriculum, both Llewellyn and Frank were early advocates of clinical legal

(1933); Symposium, Law and the Modern Mind, 31 Columbia Law Review 82 (1931); Frank J., A Plea for Lawyer-Schools, 56 Yale Law Journal 1303 (1947). For a detailed analysis of the writings of Professor Frank, see Kruse K., Getting Real About Legal Realism, New Legal Realism and Clinical Legal Education, Faculty Scholarship Paper 382 (2011).

3 See, Frank Why Not a Clinical Lawyer-School? (1933), supra, p. 914-915 (“[t]he lawyer must learn the jargon of the courts, the art of judicial rhetoric. The exclusively book lawyer can perhaps best teach such 'library-law'. [Therefore,] 'library-law' teacher[s] should cease to dominate the schools ... [but] [u]nfortunately, attempted reform of legal pedagogy is frequently in [their] hands.").

$4 \quad$ See, Frank Why Not a Clinical Lawyer-School? (1933), supra, p. 917 (“... now we come to a point which the writer considers of major importance ... law schools could learn much from the medical schools. Medical schools rely to a very large extent on the free medical clinics and dispensaries.... Suppose ... that there were in each law school a legal clinic or dispensary.... The work of these clinics would be done for little or no charge. The teacher-clinicians would devote their full time to their teaching, including such clinical work, and would not engage in private practice."). See, also, Holland L., Invading the Ivory Tower: The History of Clinical Education at Yale Law School, 49 (4) Journal of Legal Education 504 (1999), p. 508-509.

$5 \quad$ See, Llewellyn K., On What Is Wrong with So-Called Legal Education, 35 Columbia Law Review 651 (1935), p. 675 (despite the fact that "law school is needlessly abstract, and needlessly removed from life ... I do not believe, as Frank seems to, in the substitution of practice or clinic for theoretical instruction. But I believe with all my soul in the livening up, the making real, of the theoretical work by practical complement."). See, also, Llewellyn K., The Current Crisis in Legal Education, 1 Journal of Legal Education 211 (1948), which contains a critique of use of the case-method model in American law schools during the 1940s. 
education, recognising that students must learn about the "law as a means to an end rather than as an end itself." 6

The purpose of learning law through clinical legal education became more defined in the 1960s. ${ }^{7}$ In the days of Watergate and of Vietnam, advocates of clinical education passionately believed that the clinical movement, which claimed to be sensitive, egalitarian, nonhierarchical, and open would revolutionise traditional legal education and lead to reform of the profession. ${ }^{8}$ This social change revolution provided an opportunity to shift from "law school curricula ... organised around the profit system," to a model that included "considerable clinical experience ... directly concerned with the problems of the poor." 9 This altruistic cause was embraced and encouraged by the Ford Foundation, which donated several million dollars to law schools that agreed to

$6 \quad$ Barry M. et al., Clinical Education for this Millennium: The Third Wave, 7 Clinical Law Review 1 (2000), p. 12.

7 See, Barry M. et al., supra, p. 12. See, MacCrate R., Educating a Changing Profession: From Clinic to Continuum, 64 Tennessee Law Review 1099 (1997), p. 1108 (despite the fact that in the late 1950s and early 1960's "law school clinics provided an insignificant part of the total legal aid work, the importance of the clinics' educational mission was gaining recognition in the bar at large, as well as in the legal aid community."). See, generally, Meltsner M. and Schrag P., Reflections on clinical legal education, Northeastern University Press - Boston (1998).

$8 \quad$ See, Symposium: Clinical Legal Education: Reflections on the Past Fifteen Years and Aspirations for the Future, 36 Catholic University Law Review 337 (1987), p. 341. See, also, Holland L., supra, p. 514 ("[t]he social and political movements of the 1960s called lawyers to become activist reformers. Law students heard the same call and sought out work that would make their theoretical study of law relevant to the social struggle that was going on outside the walls of the law school.")

$9 \quad$ Ares C., Legal Education and the Problem of the Poor, 17 (3) Journal of Legal Education 307 (1965), p. 307-310. See, also, Feldman M., On the Margins of Legal Education, 13 N.Y.U. REV. L. E Soc. CHANCE 607 (1985), p.638 ("Even if the majority of our students go on to professional lives entirely unrelated to the lives of the poor and underrepresented, we should at the very least, impart to them an informed sense of what the legal system looks like to many Americans. If ignorance breeds intolerance, our teaching may be a potent antidote."). 
introduce legal clinics devoted to serving the poor as a permanent feature of their curriculum. ${ }^{10}$ The economic incentives offered by the Ford Foundation boosted the growth of clinical legal education exponentially throughout the United States ${ }^{11}$ and consolidated the commitment to social justice, fairness and non-discrimination, which became crucial features in the development of clinical education ${ }^{12}$ and are still fundamental in the outreach mission of law school clinics as we know them today. ${ }^{13}$

While the outward purpose of legal clinics was being shaped, an academic debate on the educational value of clinical programs arose within universities; conservative

10 See, Grossman G., Clinical Legal Education: history and diagnosis, Journal of Legal Education, 26 (2) (1974), p. 173. See, also, MacCrate, supra, p. 1111 ("[i]n 1968 the Ford Foundation took a decisive step in support of the ... clinical education movement [by providing] a funding commitment of approximately \$12,000,000."); Wizner S., The Law School Clinic: Legal Education in the Interests of Justice, Faculty Scholarship Series Paper 1843 (2002), p. 1933; Holland, supra, p. 513-517. See also the booklet Ford Foundation Grantees and the Pursuit of Justice, published by the Ford Foundation in 2000, which summarises the history and development of the foundation (available at https://www.fordfoundation.org/media/1707/2000-ford-foundation-grantees-and-the-pursuit-ofjustice.pdf).

11 See, Wizner (2002), supra, p. 1933. See, also, Dubin J., Clinical Design for Social Justice Imperatives, 51 Southern Methodist University Law Review 1461 (1998), p. 1466 ([w]ithin a few years of [the formation of the Ford Foundation program] almost half of all law schools in the country had some type of a clinical program.").

12 See, Barry, supra, p. 55. Wizner S., Beyond Skills Training, 7 Clinical Law Review 327 (2001), p. 327 ("... the clinical approach to legal education has always been rooted in a social justice mission."). See, also, Dubin, supra, p. 1505 ("[a]s a widening gulf emerges between rich and poor in American society and access to legal services becomes further removed from subordinated communities, the importance of clinical legal education's historic commitment to social justice becomes manifest. The need for law schools and universities to share their considerable resources in the struggle for justice and human dignity has scarcely been greater.").

13 See, Dinerstein R., Clinical Scholarship and the Justice Mission, 40 Cleveland State Law Review 469 (1992), p. 470-471 ("[s]ome of the best clinical scholarship examines the manner in which indigent clients experience the welfare system, housing court, and other settings that exist far from the esoteric world of appellate cases. ... By studying the settings in which legal services are provided to poor people, clinical scholars also contribute to our understanding of both the incredible hardships under which legal services lawyers function and the ways in which they unknowingly may hinder their clients' pursuit of justice."). 
faculty members opposed assigning academic credits to clinical activities, threatening their growth. ${ }^{14}$ In fact, without acknowledgement that clinical activities were a worthy copartner to traditional classroom work, students would have perceived clinical work "as no more than a therapeutic outlet." 15 This tension began to subside in the 1980s, after Professors Wizner and Curtis published the seminal article "Here's What We Do: Some Notes About Clinical Legal Education"16, which laid out their theory of clinical education, gathering widespread consensus. In their view, the clinical method of teaching law educated students to represent clients effectively in light of the social, economic and political implications of advocacy, and encouraged development of critical views of the legal system via the study and application of legal doctrines, theories, rules, procedure, and ethics. ${ }^{17}$ Coming full circle, their article invoked the writings of Professor Frank and articulated "the central belief ... that professional education involves the constant

14 See, Holland, supra, p. 524. See, also, Tushnet M., Scenes from the Metropolitan Underground: A Critical Perspective on the Status of Clinical Education, 52 George Washington Law Review 272 (1984), p. 273 ("[t]he impression of vulnerability [of clinical legal education] is strengthened by the presumption of many faculty members that clinical programs contain more unnecessary fat than do traditional classes."). See, Symposium: Clinical Legal Education: Reflections on the Past Fifteen Years and Aspirations for the Future, supra, p. 342 ("[f]or clinical education, the confrontation with the legal education establishment has taken its toll ... [and] the clinical education movement is in the throes of a serious identity crisis.") and p. 344 ("skeptical faculty members demanded that clinicians offer students something more than they would learn in the first year of working in a law firm. 'Mere skills-training,' faculty members argued, had no place in a university.").

15 Stone A., Legal Education on the Couch, Harvard Law Review 85 (2) (1971), p. 427. See, also, Aiken J. and Wizner S., Teaching and Doing: The Role of Law School Clinics in Enhancing Access to Justice, 73 Fordham Law Review 997 (2004) p. 999 ("[c]linicians were a different breed from their law professor counterparts. They were often housed in different spaces, not allowed to participate in faculty governance, and offered no job security.").

16 Wizner S. and Curtis D., Here's What We Do: Some Notes About Clinical Legal Education 29 Cleveland State Law Review 673 (1980).

17 See, Wizner (2002), supra, p. 1930. 
interaction of the theoretical and the practical, not just in the classroom and the library, but also in the settings where the profession is actually practiced." 18

Clinical legal education is arguably the most significant reform in American legal education since Christopher Langdell's invention of the case method. ${ }^{19}$ Today, law school clinics are a permanent part of the law school curriculum and continue to provide future generations of lawyers with a practical and theoretical education in law. ${ }^{20}$

After having illustrated the most significant milestones in the American clinical legal education movement, in the next section I will investigate important historical reasons why clinical education did not thrive in continental Europe, specifically focusing on the Italian context. Then, I will analyze the current developmental patterns of Italian clinical legal education and illustrate the next steps towards widespread dissemination of clinical models in law schools.

\section{The Current Framework of Italian Clinical Legal Education}

In 1935, Professor Francesco Carnelutti started advocating for the introduction of practical components in Italian law schools' curricula. Similar to Professor Frank, he

\footnotetext{
$18 \quad$ Holland, supra, p. 525.

19 See, Wizner (2002), supra, p. 1934.

20 See, Holland, supra, p. 533. See, Ellmann S. et al., Why Not a Clinical Lawyer-Journal., 1 Clinical Law Review 1 (1994), which proclaimed the formation of the Clinical Law Review, a "peer-reviewed journal devoted to issues of lawyering theory and clinical legal education."
} 
Reviewed Article - Teaching and Learning in Clinic

compared medical clinics with law clinics, but his attempt to revolutionise legal education fell flat. ${ }^{21}$

Professor Wilson investigated the reasons why clinical legal education did not find fertile grounds in European countries with a civil law tradition. ${ }^{22}$ Among these reasons, Wilson included that civil law countries usually require mandatory periods of apprenticeship before entry into the legal profession. These traineeships are designed to accomplish the very goal of clinical legal education, which is to help students shift their focus from theory to practice just before becoming attorneys. ${ }^{23}$ In Italy, for example, law school graduates have to complete an 18 month internship with an experienced attorney before sitting for the bar exam.

Further, European civil law universities have large size classes of student entering law school immediately after high school; conversely, in the United States law schools

21 See, Carnelutti F., Clinica del Diritto, 1 Rivista di Diritto Processuale 12 (1935), available at http://www.romatreprisonlawclinic.it/images/articoli/carnelutticlinicadeldirittocompressed.pdf. 22 See, Wilson R., Western Europe: Last Holdout in the Worldwide Acceptance of Clinical Legal Education, 10(7) German Law Journal 823 (2009), p. 831-836. Professor Wilson's research specifically considered the cases of Germany and France, but his findings can also be applied to Italy because of its comparable framework. For an analysis of how the movement towards uniformity in legal education that followed the Bologna Process of 1999 affected the development of clinical education in Germany, see Bücker A. and Woodruff W., The Bologna Process and German Legal Education: Developing Professional Competence Through Clinical Experiences, 9 German Law Journal 575 (2008). For a perspective on experiential learning in France, see Lempereur A., Negotiation and Mediation in France: The Challenge of Skill-Based Learning and Interdisciplinary Research in Legal Education, 3 Harvard Negotiation Law Review 151, (1998). For a perspective on how the differences between civil and common law approaches impacted on the growth of clinical programs in Europe, see, also, Genty P. M., Overcoming Cultural Blindness in International Clinical Collaboration: the Divide between Civil and Common Law Cultures and its Implications for Clinical Education, 15 Clinical Law Review 131 (2008).

$23 \quad$ See, Wilson (2009), supra, p. 832. 
are only open to applicants who have already graduated from college. ${ }^{24}$ In addition, the elevated cost of legal education in the United States naturally limits the number of students that enroll. The clinical teaching model, which requires professors to closely supervise clinical participants, is generally better served by a small class size, favoring the American model.

Wilson also noted that the majority of European civil law attorneys practice in small law firms and/or as solo practitioners. ${ }^{25}$ Pro bono clinics that offer legal services for a nominal fee have the potential to tremendously impact the capacity of attorneys to attract business from low income clients. ${ }^{26}$ Therefore, the hostility of practicing attorneys towards the clinical movement might have also played a role in the lack of success of clinical legal education in continental Europe. ${ }^{27}$

As a result, the $20^{\text {th }}$ century American debate on clinical legal education did not pervade Italian academia and discussions concerning clinical programs in Italy started

\footnotetext{
$24 \quad$ See, Wilson (2009), supra, p. 834.

25 See, Wilson (2009), supra, p. 834-835.

26 See, Wilson (2009), supra, p. 834-835. See, also, Bartoli C., Legal Clinics In Europe: for a Commitment of Higher Education in Social Justice, Diritto \& Questioni Pubbliche (2016), available at, http://www.dirittoequestionipubbliche.org/page/2016_nSE_Legal-clinics-in-Europe/DQ_2016_LegalClinics-in-Europe_specialissue.pdf, p. 94 ("bar association[s] ...[are] often suspicious that clinics could steal the[ir] market.").

$27 \quad$ See, Wilson (2009), supra, p. 834-835.
} 
developing mainly after the Bologna Process of 1999 via conferences, seminars and papers. $^{28}$

According to a recent survey conducted by Bartoli, as of 2015, Italy had 21 legal clinics in 13 different towns. ${ }^{29}$ Despite the fact that law school clinics are still very limited in number, it is possible to identify a developing Italian movement for clinical legal education, which is slowly and steadily increasing. ${ }^{30}$ This evolution has recently experienced a boost thanks to the creation of the European Network for Clinical Legal Education (ENCLE) in 2013, whose goals include building a community of academics

28 The Bologna Process is a series of ministerial meetings and agreements between European countries to ensure comparability in the standards and quality of higher-education; see, Hovhannisian L., Clinical Legal Education and the Bologna Process, 2 Public Interest Law Initiative Papers 1 (2006), p. 4. See, also, Aksamovic D. and Genty P., An Examination of the Challenges, Successes and Setbacks for Clinical Legal Education in Eastern Europe, 20 International Journal of Clinical Legal Education 427 (2014), p. 438 (“... in the last 15 or 20 years [clinical legal education] spread across Central and Eastern Europe.... [Today] the concept of [clinical legal education] is not unknown any more to European legal educators."). Examples of reports, seminars and papers concerning Italian academia include Barbera M., The Making of a Civil Law Clinic, University of Brescia, available at file:///C:/Users/UTENTEPC/Downloads/gravity_forms_12_2011_08_Marzia\%20Barbera\%20\%20Brescia\%20Legal\%20Clinic\%20-\%20final-1\%20(4).pdf; Smorto G. et al., Clinica legale. Un manuale operativo, Edizioni Next (2015), available at http://clinicalegale.it/wp-content/uploads/2015/03/clinicalegale-un-manuale-operativo.pdf; Cruciani L., «And Justice for all». Accesso alla giustizia e «law clinics» come beni comuni, Rivista Critica del Diritto Privato 307 (2012); Winkler B., "Imparare facendo" Cosa sono le cliniche legali e perché vale la pena introdurle nelle facoltà di giurisprudenza, Seminar Report, University of Brescia (2010); Heritier P., "Vico e le Law and Humanities nella clinica legale della disabilità e della vulnerabilità", Seminar on Law and Humanities (2015); Carnevale G., "Law clinic. Lo sportello 'Diritti in carcere' promosso dal Dipartimento di Giurisprudenza dell'Università degli Studi di Roma Tre e da Antigone", Report (2016); Battelli E. et al., Un sistema di giustizia a misura di minore: il ruolo delle Legal Clinics, Aracne editrice S.r.l. (2012).

29 See, Bartoli C., The Italian legal clinics movement: Data and prospects, 22(2) International Journal of Clinical Legal Education 213 (2015), p. 213, available at: http://www.northumbriajournals.co.uk/index.php/ijcle/article/view/427/811.

30 See, Bartoli (2015), supra, p. 214. See, also, Bartoli (2016), p. 59 ("[t]he data shows ... that we are not simply in the presence of a proliferation of individual clinics, but the emergence of a new trend in academia should be conveyed."). 
and practitioners involved in the promotion of justice and of quality of law teaching through clinical legal education. ${ }^{31}$

The current geographical distribution of law school clinics in Italy shows a greater presence in the northern areas (Universities of Turin, Brescia, Milan, Bergamo and Verona), a sporadic presence in the central territories (Universities of Florence, Perugia, Teramo and Rome), and few locations in the South and the islands (Universities of Naples, Bari, Sassari and Palermo).
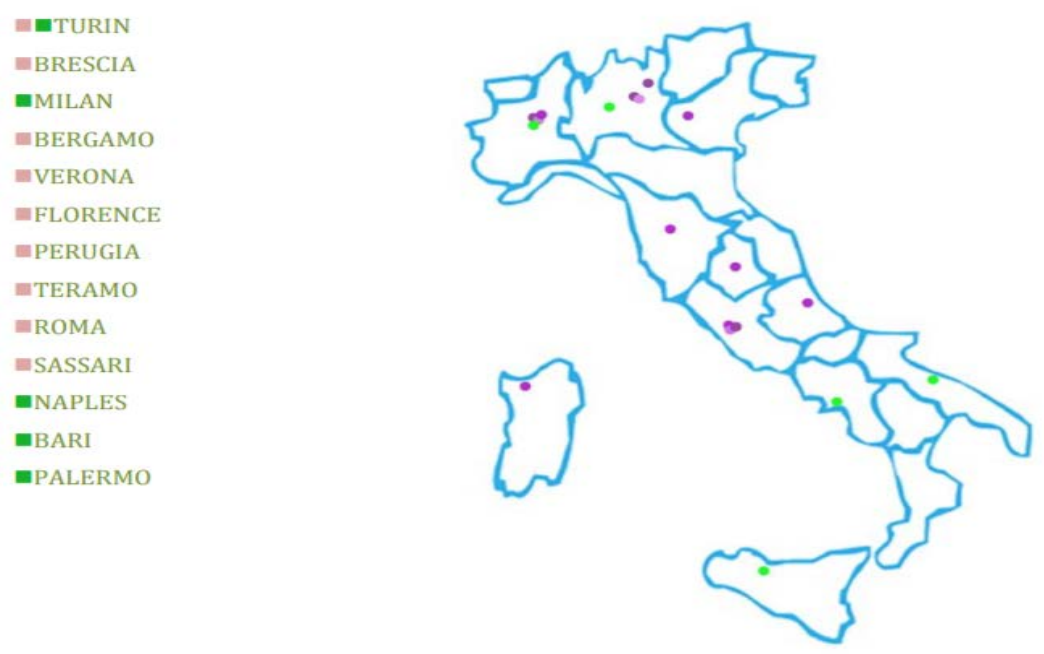

Established clinics $\quad$ Fledgling clinics

Bartoli, C., The Italian legal clinics movement: Data and prospects, Fig. 3, p. 4.

31 See, http://www.encle.org/about-encle. See, also, Tomoszek M., The Growth of Legal Clinics in Europe - Faith and Hope, or Evidence and Hard Work? 21 International Journal of Clinical Legal Education (2014), and The European Network of Clinical Legal Education: The Spring Workshop 2015, 22 International Journal of Clinical Legal Education (2015). 
As per the financial side of clinical education, "[m]oney is not the brightest aspect of this story." ${ }^{32}$ In fact, in $88 \%$ of the cases, clinics' annual budgets range from zero to approximately 15,000 Euro, and in most instances, scholars work on clinical activities without additional economic benefits and are forced to allocate funds earmarked for their research to allow clinics to survive. ${ }^{33}$ Moreover, the administrative staff usually works in the clinic for no pay. ${ }^{34}$

In addition, in Italy there is no public funding available for pro bono mediation programs. European funding exists but, as Bartoli noted, clinical programs face a highly selective process for limited resources, which makes obtaining European grants difficult and unlikely. ${ }^{35}$ In fact, "only 6\% of clinics benefits from European funds." ${ }^{36}$

\footnotetext{
$32 \quad$ Bartoli (2015), supra, p. 216.

33 See, Bartoli (2015), supra, p. 217-218.

$34 \quad$ See, Bartoli (2015), supra, p. 217-218.

35 See, Bartoli (2016), supra, p. 16.

36 Bartoli (2016), supra, p. 49-50 (when asked "«Have you ever thought about participating in a European call for funding, in order to fund the activities of your legal clinic?» ... less than $10 \%$ of the respondents [answered that they] are not interested in Union grants because they do not need them. The remainder would like to receive [European funding] but 25\% have not tried because they believe that applying for European action grants is too complicated [given that] as many as 50\% [of the programs] did not fit the right criteria. 10\% submitted an application that had not been accepted [and] about $7 \%$ ha[d] applied and received funding.").
} 

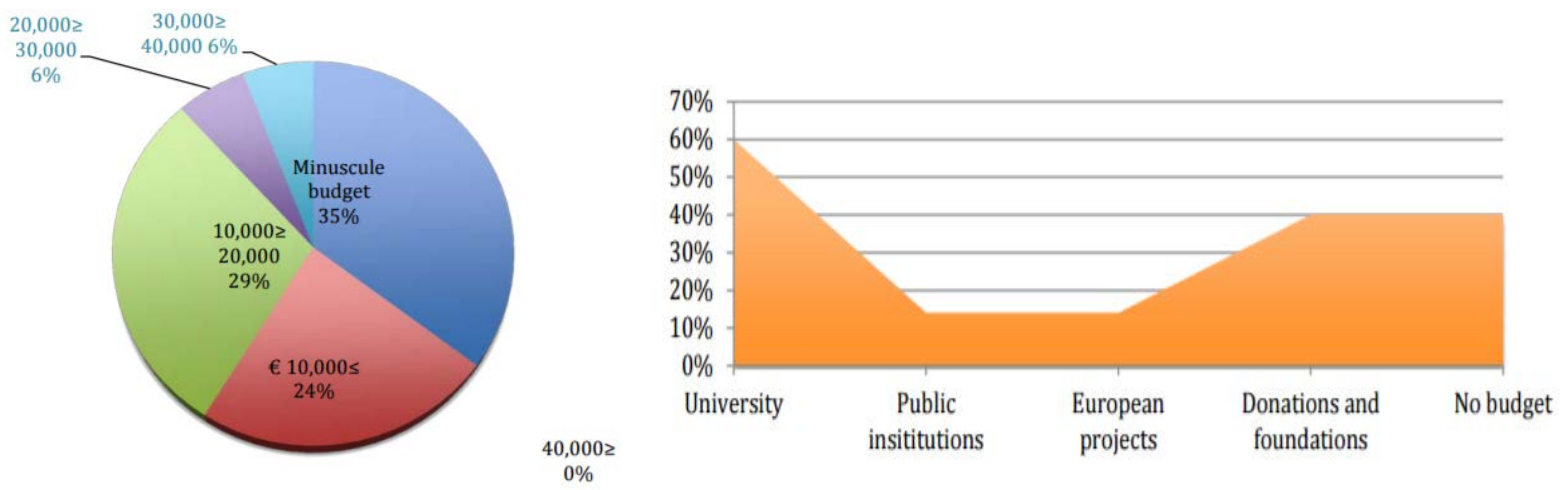

Bartoli, C., The Italian legal clinics movement: Data and prospects, Fig. 4 and 5, p. 5-6.

Given these economic constraints, Italian clinics must be creative and open to experimentation to succeed. ${ }^{37}$ The absence of common standards and institutionalisation requires each clinical program to find its own unique solution to justify its place on the official law school curriculum. Some of the most adopted options include (i) an elective seminar with credits; (ii) an internship period required to become a qualified Italian lawyer after graduation; (iii) a post-degree course; (iv) pro bono activity. ${ }^{38}$

In this apparently precarious framework, it must be noted that a common educational methodology is shared among all the Italian law clinics. ${ }^{39}$ This method consists of limiting lectures and favoring more interactive activities such as role-play, collaborative problem-solving, and above all, participation in the resolution of real cases in collaboration with lawyers. ${ }^{40}$ Interestingly, and in contrast to the American experience,

37 See, Bartoli (2015), supra, p. 220.

38 See, Bartoli (2015), supra, p. 219.

39 See, Bartoli (2015), supra, p. 220.

40 See, Bartoli (2015), supra, p. 220. See, also, Smorto G. et al., supra, p. 14-16. 
Bartoli noted that such a practical teaching style is promoted by the most theoretical members of the law faculty, who encourage and welcome a shift through a more practical and socially committed conception of law and of the profession. ${ }^{41}$

Finally, almost all Italian clinics show a strong vocation for social justice. ${ }^{42}$ In particular:

i. Italian law school clinics mainly focus on matters concerning prisons, antidiscrimination, migration, asylum, and human rights.

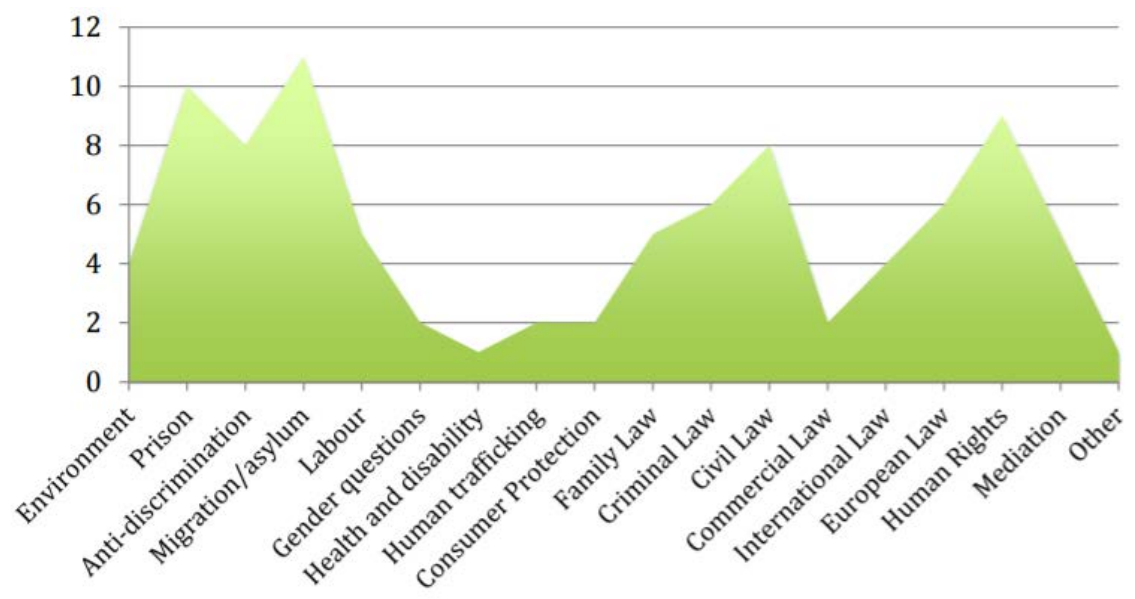

Bartoli, C., The Italian legal clinics movement: Data and prospects, Fig. 10, p. 10.

\footnotetext{
$41 \quad$ See, Bartoli (2015), supra, p. 214.

42 See, Bartoli (2015), supra, p. 222. For a perspective on the commitment to social justice and educational reform of the Immigration Law Clinic at the University of Roma Tre and the Health and Environmental Law Clinic at the University of Perugia, see Marella M.R. and Rigo E., Le cliniche legali, i beni comuni e la globalizzazione dei modelli di accesso alla giustizia e di lawyering, 33(4) Rivista Critica del Diritto Privato (2015).
} 
ii. Italian law students who participate in clinical activities develop a consistent commitment to social justice.

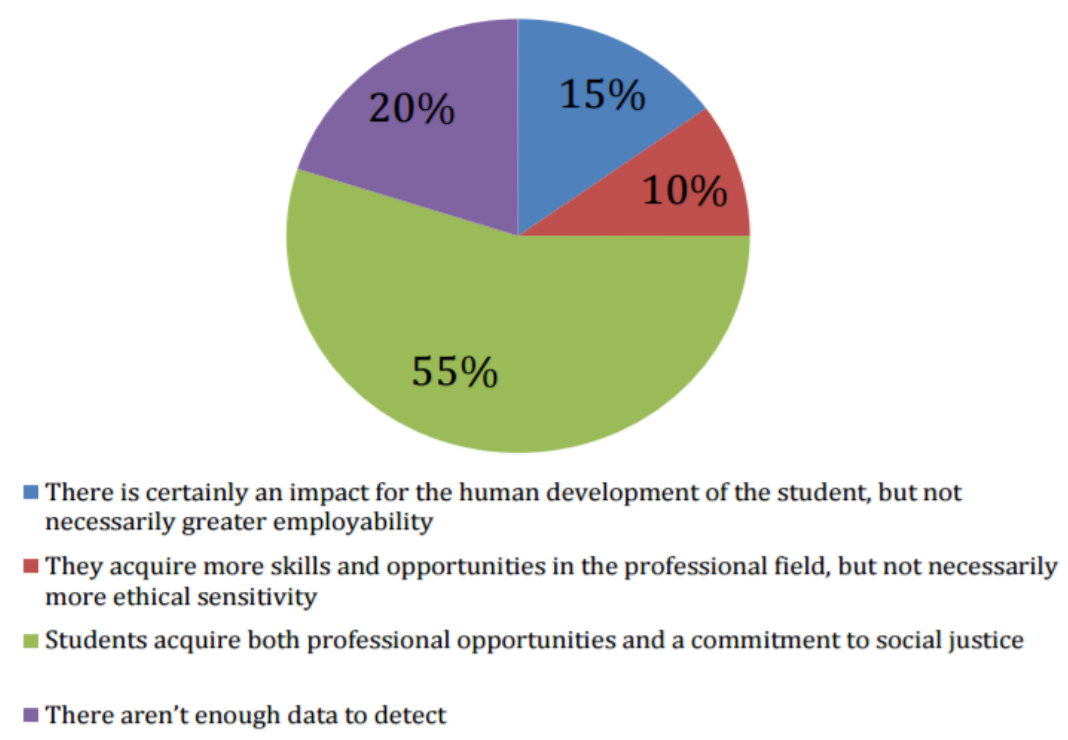

Bartoli, C., The Italian legal clinics movement: Data and prospects, Fig. 9, p. 9.

One possible explanation for this widespread commitment to social justice is that the educational framework originally developed in the United States was imported to Italy without modifications by Italian academics who studied in American law schools. Thus, it is possible that the social justice vow developed in the context of American law schools did not develop organically in Italy, and was internalised by default.

Finally, in relation to future developments in Italian clinical legal education, Bernardini argued that the goal of law school curricula should be to introduce students 
to the clinical model, shaping a new generation of lawyers that can think critically about the legal system in light of societal needs. ${ }^{43}$ The clinical legal education model, which Bernardini defined significantly unimplemented in Italian academia, can teach students how to effectively apply the knowledge acquired in the classroom to their practical experiences with the justice system. ${ }^{44}$

For these reasons, the next step in advancing clinical legal education is creating more legal clinics within Italian law schools. The following section discusses why mediation naturally lends itself to the development of an Italian legal clinic and discusses the experience of distinguished scholars in founding and evolving clinical programs on mediation.

\section{B. Founding a Mediation Clinic}

After having analysed the current framework of Italian legal clinical education, in this section I consider why mediation is particularly suited to being incorporated in a clinical program in Italy. Then, I discuss the history of the Columbia Law School Mediation Clinic through the words of its founder, Professor Carol Liebman, and analyse the framework and goals of the newly formed Columbia Law School Advanced

43 See, Bernardini M. G., Le Cliniche Legali e l'Identità del Giurista: Spunti per un Inquadramento Teorico, 27 Diritto \& Questioni Pubbliche 437 (2017) p. 453-454.

$44 \quad$ See, Bernardini, supra, p. 453-454. 
Mediation Clinic via an interview with the current director of the mediation clinics, my

mentor Professor Alexandra Carter. The purpose of these interviews was to access institutional knowledge and experience to inform the founding of a clinic, as to not "reinvent the wheel." Finally, I describe the scope of the collaboration with Libera Università Maria SS. Assunta (LUMSA).

\section{The Italian Legal Framework for Mediation}

In recent years, the European legislature strongly promoted the use of mediation. In particular, Directive 2008/52/EC ("Directive”) introduced a minimum legal framework applicable in all the Member States to harmonise fundamental rights and principles in relation to mediation in cross-border civil and commercial matters. ${ }^{45}$

The guidelines included in the Directive provide for a voluntary mediation model that leaves freedom to the parties to participate in and terminate the process at any time. ${ }^{46}$ However, courts are allowed to set procedural time-limits to regulate the duration of the process, according to relevant national laws. ${ }^{47}$ Moreover, courts are encouraged to draw

\footnotetext{
45 See, in particular, recital 7 of Directive 2008/52/EC of the European Parliament and of the Council of 21 May 2008 on certain aspects of mediation in civil and commercial matter, available at: http://eurlex.europa.eu/LexUriServ/LexUriServ.do?uri=OJ:L:2008:136:0003:0008:En:PDF. See, generally, Birch E., The Historical Background to the EU Directive on Mediation, 72(1) Arbitration: The Journal of the Chartered Institute of Arbitrators 57 (2006) and Bleemer R., The Directive Is In: European Union Strongly Backs Cross-Border Mediation, 26(6) Alternatives to the High Cost of Litigation 119 (2008). Comparatively, in the United States there is no uniformity; every state is free to autonomously regulate the practice of mediation, and most states decided not to regulate the field.

$46 \quad$ See, recitals 13 and 14 of Directive 2008/52/EC.

$47 \quad$ See, recitals 13 and 14 of Directive 2008/52/EC.
} 
parties' attention to mediation whenever appropriate and useful to achieve conflict resolution and national legislations might make the use of mediation compulsory or subject to incentives and/or sanctions, as long as such legislation does not hinder the parties' right of access to the judicial system. ${ }^{48}$

In implementing the guidelines, Member States should aim at preserving the flexibility of the mediation process and the self-determination of the parties, as well as at ensuring that the procedure is conducted in an effective, impartial and competent way. ${ }^{49}$ Mediators should be made aware of the existence of the European Code of Conduct for Mediators, available to the general public on the Internet. ${ }^{50}$ Additionally, under article 4 of the Directive, Member States shall encourage by any means which they consider appropriate the development of and adherence to voluntary codes of conduct by mediators and organisations that provide mediation services, as well as other effective quality control mechanisms.

Article 6 of the Directive provides that Member States shall ensure the possibility for the parties to request that the content of a written agreement resulting from mediation

\footnotetext{
48 See, article 8 and recitals 13 and 14 of Directive 2008/52/EC.

49 See, recital 17 of Directive 2008/52/EC.

50 See, recital 17 of Directive 2008/52/EC. The European Code of Conduct for Mediators is available online at http://ec.europa.eu/civiljustice/adr/adr_ec_code_conduct_en.pdf. For an analysis of the limitations of the European Code of Conduct for Mediators, see Menkel-Meadow C., Regulation of Dispute Resolution in the United States of America: From the Formal to the Informal to the "Semiformal", in Regulating Dispute Resolution: Adr and Access to Justice at the Crossroads: Steffek F. et al., Hart (2013), p. 426.
} 
be made enforceable, unless either the content of that agreement is contrary to the law of the Member State where the request is made or the law of that Member State does not provide for its enforceability. ${ }^{51}$ In addition, the content of an agreement resulting from mediation that has been made enforceable in a Member State should be recognised and declared enforceable in the other Member States, in accordance with applicable European or national provisions. ${ }^{52}$

Finally, mediation is intended to take place in a manner that respects confidentiality. In the absence of relevant exceptions contained in article 7 of the Directive or unless the parties agreed otherwise, Member States shall ensure that neither mediators nor those involved in the administration of the process shall be compelled to give evidence in civil and commercial judicial proceedings or arbitration regarding information shared during the mediation process.

The Italian legislature chose to implement most of the European guidelines even to its internal mediation process, as provided for by recital 8 of the Directive. ${ }^{53}$ With article 60 of the law n. 69 of June 18, 2009 (legge n. 69 del 18 giugno 2009), ${ }^{54}$ the Parliament

\footnotetext{
$51 \quad$ See, also, recital 19 Directive 2008/52/EC.

52 See, recital 20 of Directive 2008/52/EC.

53 For a detailed analysis of content of Directive 2008/52/EC and its internalisation into the Italian legal system, see , Trocker N. and De Luca A., La mediazione civile alla luce della direttiva 2008/52/CE, Firenze University Press (2011), p. 69-195; Reale M. C., La Mediazione Civile e l'Europa, 1 Sociologia del Diritto 95 (2014).

54 Available at: http://www.parlamento.it/parlam/leggi/09069l.htm.
} 
authorised the Government to transpose the content of the Directive into one or more legislative decrees. ${ }^{55}$ The Government exercised its power via legislative decree n. 28 of March 4, 2010 (decreto legislativo n. 28 del 4 marzo 2010), ${ }^{56}$ which created a national framework for the regulation of mediation in civil and commercial matters. ${ }^{57}$ Legislative decree n. 28 of March 4, 2010 (“Legislative Decree”) did not merely replicate the content of the Directive, but included unique features and policy considerations that created an original model. ${ }^{58}$

Article 3 of the Legislative Decree requires organisations that offer mediation services to be part of a register maintained by the Ministry of Justice and to adopt codes of conduct and regulations that ensure impartiality, competency and confidentiality. ${ }^{59}$ As further clarified by articles 9 and 10, confidentiality is strongly protected; it extends by default to everyone that participated in the proceedings in any capacity and prevents

$55 \quad$ For a comprehensive analysis of the debate concerning the implementation of Directive 2008/52/EC in the Italian legal system, see De Palo G. and Keller L., The Italian Mediation Explosion: Lessons in Realpolitik, 28(2) Negotiation Journal 181 (2012), p. 190-193.

56 Available at: http://www.camera.it/parlam/leggi/deleghe/10028dl.htm.

57 In the Italian system, legislative decrees (decreti legislativi) are sanctioned by article 76 of the Constitution and are commonly used to implement the content of European Directives into national legislation. For a comprehensive analysis of the Italian framework, see Sorrentino, F., Le fonti del diritto italiano, CEDAM (2015). See, also, Lupo, N., Il ruolo normativo del Governo, Il Filangieri.

Quaderno/Associazione per le ricerche e gli studi sulla rappresentanza politica nelle assemblee elettive (2010); Pizzorusso, A., L'ampliamento dei poteri normativi dell'esecutivo nei principali ordinamenti occidentali a cinquant'anni dal saggio di Enzo Cheli, in Lo Stato costituzionale la dimensione nazionale e la prospettiva internazionale: scritti in onore di Enzo Cheli, a cura di Paolo Caretti e Maria Cristina Grisolia, Il Mulino, Bologna (2010).

58 See, Canale G., Il Decreto Legislativo in Materia di Mediazione, 65(3) Rivista di Diritto Processuale 616 (2010) p. 618 (the Legislative Decree included significant modifications - "significative modifiche" from the framework authorised by the Parliament, which reflected the content of the Directive).

$59 \quad$ See, also, article 16 of the Legislative Decree. 
disclosure of information shared in mediation in the event the dispute is later brought to court. To guarantee self-determination, however, parties remain free to exclude any duty of confidentiality. To assure impartiality, article 14 charges mediators with a duty to sign a declaration of impartiality before taking on a case.

Article 4 imposes a duty on lawyers to inform their clients of the possibility of using mediation before litigating. In the event that lawyers fail to properly inform their client in writing, the contract of representation is voidable. ${ }^{60}$ Article 5 of the Legislative Decree states that disputes involving landlords/tenants, rights in rem, inheritances, medical malpractice, defamation, damages caused by vehicles and boats, consumers and banks/insurances companies must go through mediation as a preliminary condition to access the court system. Thus, this provision effectively introduced mandatory mediation for selected disputes and gave the option to the parties to voluntarily select mediation for residual matters. ${ }^{61}$

\footnotetext{
$60 \quad$ See, article 4 of the Legislative Decree.

61 See De Palo G. and Keller L., supra, p. 184 ("Italy used the need to implement the European mediation directive ... [to introduce] mandated pretrial meditation for some civil and commercial disputes. [This was] a dramatic step ... It was, however, a necessary step given that ... Italian litigants have failed to embrace mediation and instead have continually chosen to bring their cases to the overburdened, slow, and inefficient judicial system."). The authors also note that in 2010 "the case backlog in Italy grew to 5.4 million cases with parties waiting an average of eight years for their day in court." (see, p. 183). For a different view on mandatory mediation see, Giuggioli P., La mediazione per la conciliazione: strumento utile se scelto liberamente dalle parti, Quarto rapporto sulla diffusione della giustizia alternativa in Italia 147 (2011), p. 155. Giuggioli argues that only a non-mandatory mediation scheme can positively affect the backlog of pending civil cases and preserve the principle of self-determination of the parties. In 2012, the Italian Constitutional Court declared the unconstitutionality of certain provisions of the Legislative Decree concerning the introduction of mandatory mediation as a precondition to have access to the court system because the Government exceeded the mandate to legislate conferred upon it
} 
Article 12 states that the agreement reached by the parties can be made enforceable by the court after a lightened scrutiny focused on certifying that the arrangements made are not contrary to public policy or against the law. The approved agreement is exempted from any fee when its value is under $€ 50.000$ and it represents valid legal title to obtain repossession and commence an attachment proceeding. ${ }^{62}$

The Legislative Decree also delegated to the Ministry of Justice the task of identifying detailed technical provisions concerning, in particular, educational requirements imposed on registered mediation service providers and costs of the proceedings. ${ }^{63}$ Minister of Justice decree n. 180 of October 18, 2010 (decreto del Ministro della Giustizia n. 180 del 18 ottobre 2010) ${ }^{64}$ completed the legal framework of Italian mediation, determining the criteria that educational institutions must follow in order to be included in the register for organisations qualified to educate mediation practitioners. ${ }^{65}$

\footnotetext{
by the Parliament (see, opinion of the Italian Constitutional Court n. 272 of December 6, 2012, available at: https://www.cortecostituzionale.it/actionSchedaPronuncia.do?anno=2012\&numero=272).

62 See, article 12 of the Legislative Decree.

63 See, articles 16 n. 2 e 5 and 17 n. 4 of the Legislative Decree.

64 Available at: http://www.gazzettaufficiale.it/gunewsletter/dettaglio.jsp?service=1\&datagu=2010-

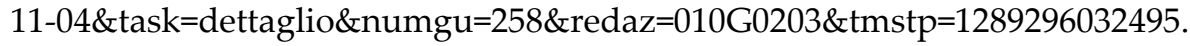

65 Ministerial decree n. 180 of October 18, 2010 was partially modified by ministerial decree n. 145 of July 6, 2011 (decreto ministeriale n. 145 del 6 luglio 2011, available at: http://www.normattiva.it/urires/N2Ls?urn:nir:stato:decreto.ministeriale:2011-07-06;145!vig=) to address limited reservations expressed by the State Attorney office (Avvocatura dello Stato).
} 
As provided by article 18 of ministerial decree n. 180 of October 18, 2010 ("Ministerial Decree"), registered organisations must have a share capital of at least $€ 10.000$, a physical location, honorable members, a minimum of five competent and qualified educators, trainings of at least 50 hours on mediation theory, practice, and roleplay for a maximum of 30 participants, a final test of 4 hours or more on both theory and practice. The trainings must focus on national, European and international mediation rules, facilitative and evaluative methodologies, contractual mediation clauses, form, content and effects of requests to mediate and mediation agreements, duties and responsibility of mediators. In addition, the institutions must organise advanced trainings of the duration of 18 hours every two years and provide for the online publication of information concerning its trainings. Educational institutions must also appoint an individual with a strong reputation and experience in the field of mediation as coordinator of their programs.

Shortly after the Ministerial Decree was introduced, it became clear that the adopted provisions were not sufficient to adequately address some controversial procedural and substantive issues. The Ministry of Justice then started adopting ministerial circulars and directives to remedy the emerged deficiencies. ${ }^{66}$ To safeguard the quality of the process, Ministerial circular of June 13, 2011 (circolare Ministero della

\footnotetext{
66 For a comprehensive summary of all the provisions concerning mediation in Italy, see https://www.giustizia.it/giustizia/prot/it/mg_1_8.wp?selectedNode=0_18.
} 
giustizia del 13 giugno 2011 ${ }^{67}$ restricted the practice of mediation to individuals who hold a three-year university degree or are registered with certain professional associations and limited the role of educators to practitioners who produced scientific publications on mediation in journals with nationwide diffusion. Ministerial circular of December 20, 2011 (circolare Ministero della giustizia del 20 dicembre 2011) ${ }^{68}$ addressed problematic aspects concerning supervision and control over the registered mediation institutions, continued education, case assignment and conclusion of the proceedings. Ministerial circulars of November 27, 2013 (circolare Ministero della giustizia del 27 novembre 2013) ${ }^{69}$ and of December 3, 2013 (circolare Ministero della giustizia del 9 dicembre 2013) ${ }^{70}$ better defined the role of attorneys in the mediation process, stating that attorneys cannot act as mediators without being affiliated to a registered institution. Ministerial circulars of November 15, 2013 (circolare Ministero della giustizia del 15 novembre 2013) (11 $^{71}$ and of October 22, 2014

$67 \quad$ Available at:

https://www.giustizia.it/giustizia/it/mg_1_8_1.page;jsessionid=nRbhAD2uQBJXqjHHQhjoXjt2?facetNode _1=1_1(2011)\&facetNode_2=1_1(201106)\&facetNode_3=0_10\&contentId=SDC645583\&previsiousPage=mg -1_8.

$68 \quad$ Available at:

https://www.giustizia.it/giustizia/it/mg_1_8_1.page?facetNode_1=0_18\&contentId=SDC718215\&previsiou sPage=mg_1_8.

$69 \quad$ Available at:

https://www.giustizia.it/giustizia/it/mg_1_8_1.page?facetNode_1=0_18\&contentId=SDC971358\&previsiou sPage=mg_1_8.

$70 \quad$ Available at:

https://www.giustizia.it/giustizia/it/mg_1_8_1.page?facetNode_1=0_18\&contentId=SDC974986\&previsiou sPage=mg_1_8.

$71 \quad$ Available at:

https://www.giustizia.it/giustizia/it/mg_1_8_1.page?facetNode_1=0_18\&contentId=SDC964753\&previsiou sPage=mg_1_8. 
(circolare Ministero della giustizia del 22 ottobre 2014) ${ }^{72}$ laid out the procedure that registered mediation service providers must follow to report statistical returns on their mediations.

In 2014, Minister of Justice decree n. 139 of August 4, 2014 (decreto del Ministro della Giustizia n. 139 del 4 agosto 2014) ${ }^{73}$ modified the Ministerial Degree, adding article 14-bis on conflict of interest. In particular, the new provision declared that a mediator affiliated with an organisation cannot:

- be a party in a mediation administered by that organisation nor assist parties in relation to disputes that are pending;

- mediate a dispute in case she is personally related to, acquainted with or had a professional relationship in the past two years with any of the parties;

- maintain a professional relationship with any of the parties during the two years that follow resolution of a case.

Interestingly, article 14-bis expressly incorporates by reference the provisions of article 815 of the Italian Code of Civil Procedure, which lists the situations in which arbitrators must recuse themselves because of a conflict of interest. In applying the same conflict of interest rules to both arbitrators and mediators, the Italian Government

$72 \quad$ Available at:

https://www.giustizia.it/giustizia/it/mg_1_8_1.page?facetNode_1=0_18\&contentId=SDC1076192\&previsio usPage=mg_1_8.

73 Available at: http://www.normattiva.it/uri-res/N2Ls?urn:nir:stato:decreto.ministeriale:2014-08$04 ; 139$ ! vig=. 
decided to set a uniform standard. However, after the introduction of article 14-bis it remained unclear whether the principles of autonomy and self-determination allowed the parties to knowingly appoint a mediator with an apparent conflict of interest. Ministerial circular of July 14, 2015 (circolare Ministero della giustizia del 14 luglio 2015) ${ }^{74}$ determined that the importance of preventing conflict of interest and guaranteeing that mediators are both neutral and impartial is such that the parties are prohibited from appointing a conflicted mediator. ${ }^{75}$

In April of 2016, however, the Regional Administrative Court of Latium (Tribunale Amministrativo Regionale del Lazio) annulled article 14-bis and the Ministerial circular of July 14, 2015 because the Government exceeded the authority conferred upon it by the Parliament. ${ }^{76}$ In fact, the court noted that legislative decree n. 28 of March 4, 2010 did not confer upon the Government any power to regulate on mediators' conflict of interest. ${ }^{77}$ The Court also observed that regulations and codes of conduct adopted by registered organizations assume a central role in the mediation process, including the function of

$74 \quad$ Available at:

https://www.giustizia.it/giustizia/it/mg_1_8_1.page?facetNode_1=0_18\&contentId=SDC1164399\&previsio usPage=mg_1_8.

75 See, Perrotta G., Il conflitto di interessi tra la figura del mediatore civile e quella dell'avvocato: i chiarimenti del Ministero della Giustizia, 2(2) La Nuova Giustizia Civile 43 (2015), p. 46.

$76 \quad$ See, TAR Lazio Roma, sez. I, Judgment n. 3989 of April 1, 2016, available at:

http://webcache.googleusercontent.com/search?q=cache:oTyVz6tPAFYJ:www.ordineavvocaticivitavecchi a.it/wp-content/uploads/2015/10/Sentenza-TAR-Lazio-n.-3989-del-

2016.docx+\&cd=20\&hl=en\&ct=clnk\&gl=us.

77 See, TAR Lazio Roma, sez. I, Judgment n. 3989 of April 1, 2016, supra. 
exclusively stating the criteria that assure that mediators are substantially impartial and neutral. ${ }^{78}$

Since the appearance of the Directive in 2008 the Italian legal framework on mediation keeps evolving at a fast pace and often in a disjointed way, as demonstrated by the various governmental interventions that repeatedly clarified, corrected and modified previously obscure provisions. The normative patchwork adopted by the Government was capable of addressing only specific issues at a time, demonstrating obvious shortcomings in the regulation of mediation as a whole, and partially failed to survive the judicial scrutiny of the courts. Many controversial and difficult ethical, substantive and procedural questions posed by mediation remain left to the interpretation of individual practitioners and organisations. ${ }^{79}$ This relativism certainly creates tensions that only an organic and structured development of mediation theory and practice can solve.

Despite this clear educational need, to this day very few Italian Law Schools include specific courses concerning the theory and practice of mediation. To solve this

78 See, TAR Lazio Roma, sez. I, Judgment n. 3989 of April 1, 2016, supra. Article 7(3) of the Minister of Justice decree n. 180 of October 18, 2010 states that the regulations adopted by registered mediation service providers must include provisions concerning mediators' conflict of interests.

79 See, De Palo G. and Keller L., supra, p. 197 ("[w]hether the Italian mediation decree will ultimately be a successful measure for Italian dispute resolution is uncertain, and the practical and scholarly debates on the more controversial aspects of the law will continue."). 
deficit and prepare future practitioners in the field of mediation, a clinical program focused on mediation would:

- comply with all the requirements imposed on mediation service providers for admission to the register maintained by the Ministry of Justice; ${ }^{80}$

- provide students with foundational skills and understanding of theory and practice of mediation;

- guarantee substantial opportunities to gather practical experience. Because mediation is a flexible and relatively expedite process within just a semester students would be able to observe the entire cycle of many disputes, from their inception to potential resolution;

- offer chances to practice mediation directly and under the supervision of experienced practitioners, fulfilling the learning-by-doing approach typical of clinical legal education;

- foster the social justice commitment of clinical education. The potential scope of mediation is limited only by the creativity of the people who practice it; mediation services can be provided at nominal or at even no fee in settings that range from two parties in conflict to large communities in disagreement, covering a wide spectrum of disputes;

80 See, article 18 of the Legislative Decree, above. 
- operate both in formal contexts, like a court room, and in more informal places, like the law school premises or private locations;

- interplay with many other courses in the law school curriculum, for example family law, civil law, international law, negotiation, etc.

After having illustrated the need for and potential of an Italian mediation clinic, I will dedicate the upcoming sections to the experiences of two great mediation scholars in founding, developing and advancing clinical programs on mediation in the United States. These sections are designed to share insightful knowledge and practical guidance that can inform the creation and growth of an Italian mediation clinic.

\section{How to Create a Mediation Clinic: The Columbia Law School Example}

Having observed the potential educational impact and benefits of a mediation clinical program, I will now discuss the steps necessary to set up a mediation clinic program, taking advantage of the institutional knowledge provided by Professor Carol Liebman, founder of the Columbia Law School Mediation Clinic. ${ }^{81}$

Professor Liebman's interest in mediation developed while representing the Massachusetts State Department of Correction in federal civil rights cases brought by

81 As mentioned in the first paragraph of section B, above, the information that follows concerning Professors Liebman and Carter comes from a series of interviews that I personally conducted with them in 2016-2017. 
prisoners. She understood that issues raised by inmates frequently did not amount to the civil rights violations they claimed; they mainly involved managerial problems that litigation could not properly address. In fact, litigation fell short in helping people to engage in dialogue and to understand interests and worries behind their respective positions. Professor Liebman saw a need to find mutually acceptable solutions that considered both parties' concerns, and realised that prison grievance panels which used a mediation approach were the most appropriate tool because they could achieve broader results than adjudicative dispute resolution methods, as well as satisfy various needs. In particular, mediation could empower parties to engage in a productive conversation in order to reach a solution that is satisfying, durable and flexible.

While teaching in the legal aid clinic, Professor Liebman continued to practice mediation as a volunteer mediator, attend conferences, and network with practitioners within the mediation community. During this time, the Dean of Boston College Law School asked her to run a simulation course on mediation. Her original curriculum included a day and a half training on basic skills and role plays, followed by weekly interactive classes, lectures and discussions concerning mediation theory, practice and policy issues. ${ }^{82}$ When Liebman moved to Columbia Law School, she founded the

82 Among the benefits of having interactive group conversations led by students, Professors Bryant and Milstein include that students "(1) ... can immediately see relevance to their work; (2) ... develop insights for contextual thinking, explore professional identity, and find support for stressful work; (3) ... apply, test, and refine lawyering theory while simultaneously developing professional norms."; see, 
mediation clinic. ${ }^{83}$ The clinic year began with four days of intensive skills training spread over two weekends followed by closely supervised mediation of actual cases and weekly classes. In addition, students were required to write journals that analysed their mediation experiences. Journals created an opportunity for students to self-reflect; they had to review their practical conduct in light of the guidelines learned in class and through the assigned readings. Moreover, Professor Liebman committed to read all the journals and to provide students with prompt, regular, and tailored feedback.

Simultaneously, Professor Liebman had to perform extensive outreach work to identify suitable organisations to partner with in order to find a solid caseload capable of providing clinical students with opportunities to mediate on a weekly basis. This was one of the most challenging tasks; it required considerable time and effort to create and continuously nurture relationships with partner institutions. In addition, she used to personally supervise every mediation (up to five every week). Liebman later used teaching assistants to oversee some of the mediations, achieving two goals. First, Professor Liebman gained more freedom to perform other activities necessary to run the

Bryant S. and Milstein E., Rounds: A “Signature Pedagogy" for Clinical Education?, 14 Clinical Law Review 195 (2007), p. 206-207.

83 For an analysis of the history and development of Columbia Law School's clinical programs given directly by the founding faculty members, see the video-conference "History in the Making: The Origins of Clinical Education at Columbia Law School", available at http://www.law.columbia.edu/clinics-celebration-2015/recap/videos\#history. 
clinic. Further, alumni of the clinic had the valuable opportunity to observe, advise, and coach other students, reinforcing their skills and gaining academic credits for their work.

After hearing about the development of the Columbia Law School Mediation Clinic, I asked Professor Liebman to recommend some best practices for creating a new mediation clinic. She suggested the adoption of a:

1. non-evaluative model, which gives inexperienced students freedom to learn the basic principles of mediation without providing legal advice; and

2. co-mediation system, which relieves individual students of some pressure, builds team collaboration, and helps understanding different individual mediation styles.

Lastly, she emphasised the importance of focusing on teaching the boundaries of confidentiality, clearly explaining its limits and exceptions.

After having described the development of the Columbia Law School mediation clinic, the next section will illustrate how the original educational framework recently evolved into an advanced model. This addition to the clinical programs at Columbia Law School was designed to provide students with the opportunity to enhance the lawyering skills internalized in the mediation clinic, to mentor other students and to encourage both creativity and responsibility via the creation of original educational content and management of the trainings. 


\section{The Columbia Law School Advanced Mediation Clinic}

Before the creation of the Columbia Law School Advanced Mediation Clinic, Professor Alexandra Carter and Lecturer in Law Shawn Watts received various requests from outside organisations to develop projects and ad hoc mediation training sessions. They would either embark into these tasks individually or with selected students, but without being able to provide a continuous learning experience. This state of affairs changed in the summer of 2016, when the Mediation Clinic signed a partnership with the United Nations to provide a series of conflict resolution trainings that lie in the intersection of alternative dispute resolution and several of the United Nations' sustainable development goals. At that point, Carter and Watts had a solid source of work to develop a new generation of clinical education programing within Columbia Law School; students who showed commitment and performed well academically while in the Mediation Clinic had an opportunity to work closely with the clinical faculty, receiving insights on how to teach mediation, run a clinic, and advance the goals of the Advanced Mediation Clinic.

In particular, the Advanced Mediation Clinic's students are expected to help the faculty members to (i) promote the use of mediation across the country and internationally; (ii) discuss critical issues along the growth edge of mediation practice, like language barriers, generational gaps, cultural differences, ethical dilemmas; (iii) further their understanding of various styles of mediation; (iv) actively participate in 
designing customised curricula concerning conflict resolution methods; (v) have direct interactions with clients; (vi) act as teaching assistants, coaching other students through discussion of common issues experienced; and (vii) assist in building a strong community of colleagues who support each other in pursuing individual interests concerning theory and practice of mediation.

In addition to the activities relating to the established partnership with the United Nations, the first year of the Advanced Mediation Clinic was characterised by the development of new projects initiated by graduates of the mediation clinic.

After a nationwide rise in political polarisation that followed the 2016 United States presidential election, an alumnus and current associate at Morrison and Foerster LLP approached the partnership and proposed teaming up with the Columbia Law School Advanced Mediation Clinic to create a conflict resolution training seeking to empower attorneys and staff with tools to safely deal with political and identity-related conflicts. A group of students created a custom-designed conflict de-escalation training that focused on best practices to approach micro-aggressions outside the work environment. The training was successfully run at the firm's San Francisco and New York offices, making Morrison and Foerster LLP the first major law firm to host such events.

In the spring of 2017, an alumna who was clerking for the Alaska Court of Appeal approached Professor Carter and Lecturer Watts to perform training on mediation skills 
and ethics in Anchorage, Alaska. Students from the Advanced Mediation Clinic designed a tailored training focused on facilitative mediation, party self-determination, language, generational, and cultural barriers. The training was conducted before a crowd of Alaska state judges, mediators from local small claim courts, and lawyers of the Anchorage Bar Association, who actively engaged in the session and contributed to the success of this event.

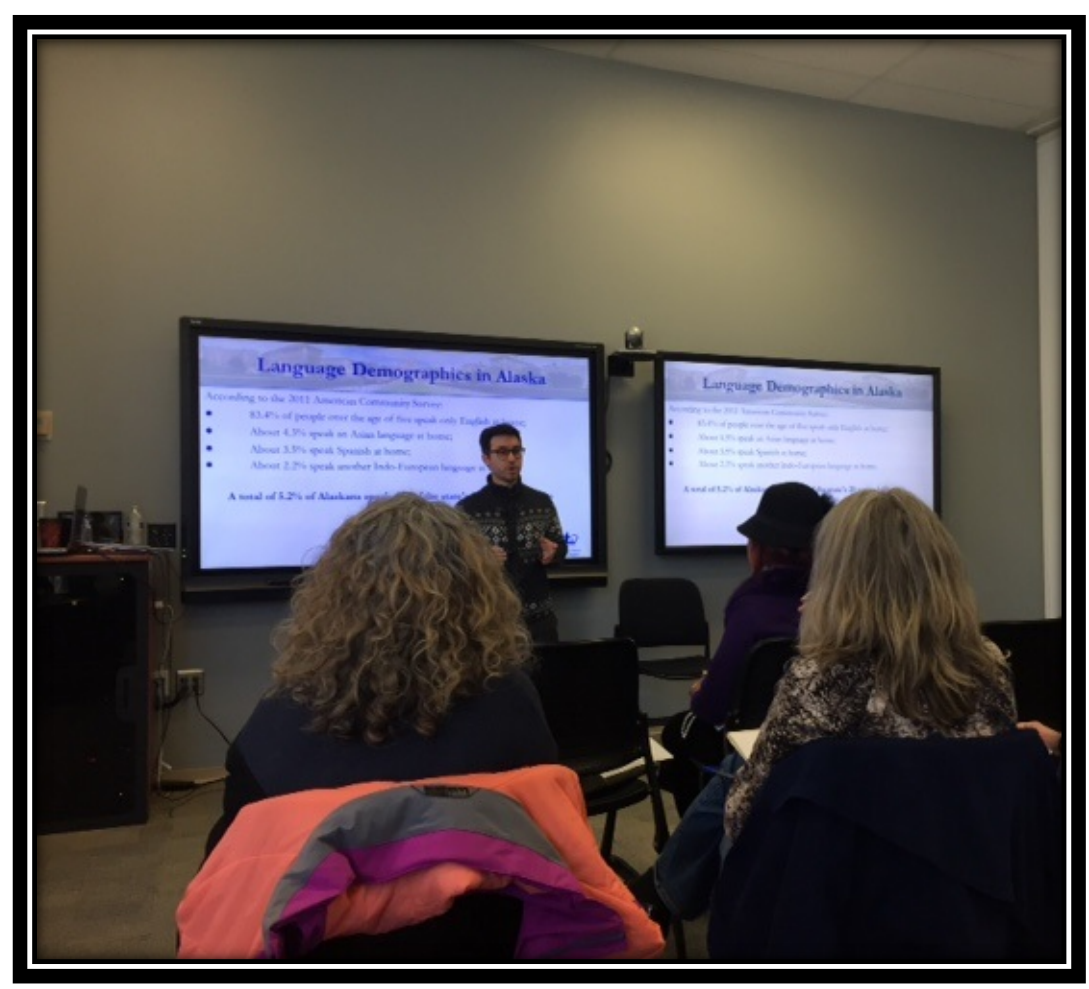

Picture of the Author facilitating part of the mediation training in Anchorage, Alaska.

Not to mention, the Columbia Law School Advanced Mediation Clinic has other positive and ground breaking effects. First, it offers students opportunities to develop curricula, run trainings and learn how to teach, which are extremely beneficial skills for 
students who want to pursue a career in academia, and usually lay outside most of law schools' academic offerings. Second, it generates revenue in the forms of donations, which help the clinic fund its other pro bono projects. Lastly, it keeps alumni connected with the mediation clinic community after graduation, helping them promoting mediation in different practice areas and countries.

In conclusion, Columbia Law School Advanced Mediation Clinic's first year was a great success. This model shows extraordinary potential for fostering the goals of clinical education and offers other law schools incentives to implement similar programs in their curricula.

Having described the evolution of Columbia Law School's mediation programs, I will now discuss the inception and evolution of the relationship with LUMSA and the dialogue that identified the mediation services that the clinic ought to offer.

\section{Vision for an Italian Mediation Clinic: The LUMSA Project}

In the context of my activities both in Columbia Law School's Mediation Clinic and Advanced Mediation Clinic, I started advocating for the promotion of mediation in Italy, receiving great support from Professor Carter and Lecturer Watts, as well as from the law faculty of Libera Università Maria SS. Assunta (LUMSA) to pursue the ambitious goal of laying the foundations for an Italian mediation clinic. 
In December 2016, I met in Rome with LUMSA Professor Emanuele Odorisio to discuss the scope of my research and how to implement it within LUMSA's curriculum. At that time, LUMSA was in the process of starting its first clinic on employment litigation and was thinking about other ways to expand its legal clinics programs. We wanted to identify the core structure of the proposed mediation clinic, mindful of the financial budget that LUMSA could invest in the creation and operation of the proposed clinic-which was in line with the majority of Italian law schools, as seen in paragraph A.II. In particular, we had to pinpoint what kind of mediation services the clinic would provide to the public and how to best assure a solid caseload.

During our dialogue, it emerged that LUMSA had long-lasting connections with Catholic communities and other nonprofit organisations in the Rome area that focus on helping families in need. We recognised in those connections a valuable opportunity to provide the clinic with a solid caseload and to pursue the social justice commitment that characterises clinical legal education. ${ }^{84}$ We agreed to focus this research on introducing mediation via a clinical teaching model focused on family and community disputes, and decided to tailor the curriculum to both the legal and educational needs of the families and communities LUMSA and the clinic hopes to serve.

\footnotetext{
$84 \quad$ For an analysis of the social justice commitment of clinical legal education, see sections A.I, A.II and B.I, above.
} 
Having clarified scope and mission of the LUMSA clinic, the following section describes mediation and its models, focusing specifically on the evaluative vs. nonevaluative debate. Then, it analyses how various non-evaluative schemes have been implemented in family mediation programs.

\section{Considerations and Recommendations for Creating a Family Mediation Clinic at LUMSA}

\section{Mediation: Understanding the Models}

Mediation is a form of alternative dispute resolution (ADR) wherein "the parties meet with a mutually selected impartial and neutral person who assists them in the negotiation of their differences." ${ }^{85}$ A general definition of mediation must necessarily remain broad and include only the distinctive features that distinguish mediation from other ADR methods. In fact, the majority of scholars agree that a single limiting definition of mediation does not exist because of different philosophies and styles embraced and adopted by mediators. ${ }^{86}$

85 "Mediation Defined: What is Mediation?" JAMS Mediation Services, available at https://www.jamsadr.com/mediation-defined/.

86 See, Levin M., The Propriety of Evaluative Mediation: Concerns About the Nature and Quality of an Evaluative Opinion, 16 Ohio St. J. Disp. Resol. 267 (2000-2001), p. 267. See, also, Rubinson R., Of Grids and Gatekeepers: The Socioeconomics of Mediation, 17 Cardozo Journal of Conflict Resolution 837 (2016), p. 877 ("[t]here is no consensus" on a definition of mediation); Charkoudian L. et al., Mediation by Any Other Name Would Smell as Sweet-Or Would It? The Struggle to Define Mediation and Its Various Approaches, 26 Conflict Resolution Quarterly 293 (2009), p. 313 (there is no common definition of "approaches to mediation"). 
The first attempt to systematically define and categorize various approaches is attributed to Professor Leonard Riskin, who presented a diagram that became known as the Riskin's grid. ${ }^{87}$ Riskin recognized that there was no comprehensive or widely accepted system for classifying mediator conduct. For this reason, he created a method to distinguish among various processes that were commonly called mediation. ${ }^{88}$ Riskin's grid contains four quadrants illustrating the mediator's orientation. These quadrants "are based on two continuums. One continuum, concerning the mediators' activities, ranges from pure evaluative to pure facilitative mediation approaches. The second continuum, dealing with the goals of the mediator, measures the scope of the issues that mediation seeks to address or resolve." 89

87 See, Riskin L., Mediator Orientations, Strategies and Techniques, 12 Alternatives To High Cost Litigation 111 (1994) and Riskin L., Understanding Mediators' Orientations, Strategies, and Techniques: A Grid for the Perplexed, 1 Harvard Negotiation Law Review 7 (1996). Riskin then proposed two modified diagrams. The first, called "The New Old Grid", appeared in Riskin L., Who Decides What? Rethinking the Grid of Mediator Orientations, Dispute Resolution Magazine (2003), and Riskin L., Retiring and Replacing the Grid of Mediator Orientations, 21 Alternatives To High Cost Litigation 69 (2003). The second model, labeled "The New New Grid", is described in Riskin L., Decisionmaking in Mediation: The New Old Grid and the New New Grid System, 79 Notre Dame Law Review 1 (2003).

88 See, Riskin L., Decisionmaking in Mediation: The New Old Grid and the New New Grid System, 79 Notre Dame Law Review 1 (2003), p. 4.

89 McDermott, P. and Obar, R., "What's Going On" in Mediation: an Empirical Analysis of the Influence of a Mediator's Style on Party Satisfaction and Monetary Benefit, 9 Harvard Negotiation Law Review 75 (2004), p. 76. 


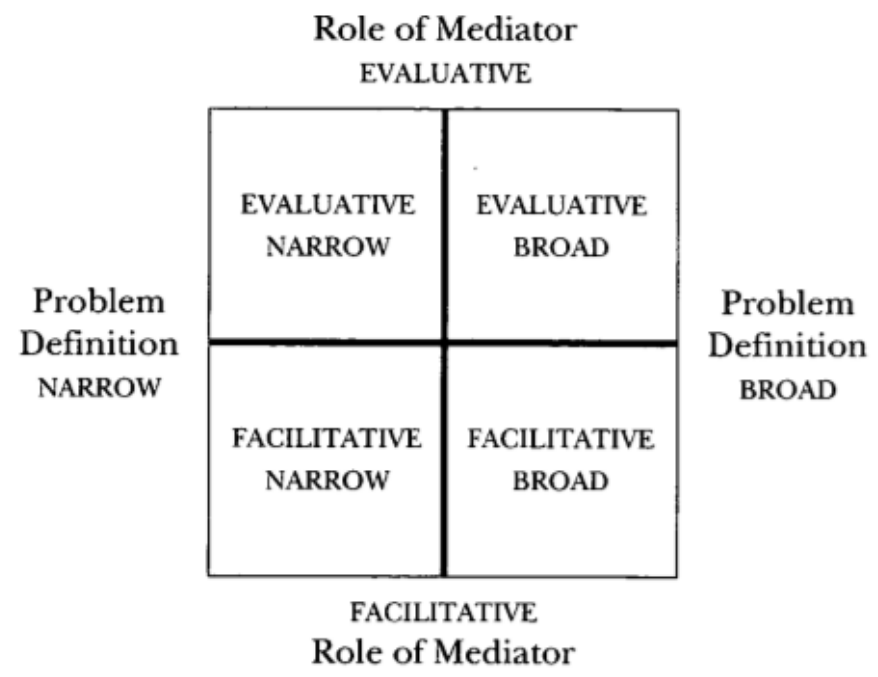

Riskin's original grid (1994-1996)

Riskin's grid generated the first major split in mediation models and fostered a fierce debate on non-evaluative and evaluative mediation and appropriate role and goals for mediators..$^{90}$ The approach adopted and the conduct assumed by the neutral are the distinctive features that differentiate these two major models.

90 See, Love L. and Waldman E., The Hopes and Fears of All the Years: 30 Years behind and the Road Ahead for the Widespread Use of Mediation, 31 Ohio State Journal on Dispute Resolution 123 (2016), p. 138 ("Riskin's grid was the graphic representation of a field becoming confused about its primary focus and direction. The grid legitimized some of the evaluative practices that are now the norm in many venues. These practices moved us ever farther from the emphasis on understanding, problem-solving, and party engagement that animated mediation's original vision."). In relation to the debate on the facilitative-evaluative continuum, see, also, Kovach K. and Love L., Mapping Mediation: The Risks of Riskin's Grid, 3 Harvard Negotiation Law Review 71 (1998). See, also, Lowry R., Training Mediators For The 21st Century: To Evaluate or Not: That is Not the Question!, 38 Fam. \& Conciliation Cts. Rev. 48 (2000); Alfini J. et al., Evaluative Versus Facilitative Mediation: A Discussion, 24 Fla. St. U. L. Rev. 919 (1997); Birke R., Evaluation and Facilitation: Moving Past Either/Or, J. Disp. Resol. 309 (2000); Love L., The Top Ten Reasons Why Mediators Should Not Evaluate, 24 Fla. St. U. L. Rev. 937 (1997). The debate on the narrow-broad continuum has drawn less attention: the main critique comes from Riskin himself, who points out the structural problems of this classification (it obscures "the dynamic relationships between different problem-focuses, the approaches and strategies of the mediator, and the wishes and actions of 
Evaluative mediators focus on identifying the parties' legal rights and obligations and on providing them with a knowledgeable and objective third-party assessment of the strengths of their respective claims. ${ }^{91}$ Ultimately, these mediators are asked to prognosticate how a potential judge or jury is likely to adjudicate the case, so that the parties can decide the best course of action going forward. ${ }^{92}$ This procedure requires discussing the difficulties of litigating a case, the shortcomings and weaknesses of the arguments proposed, as well as offering guidance concerning the substantive legal issues and the likelihood of success of each demand. ${ }^{93}$ Parties are invited to formulate offers in line with the mediator's suggestions and to reach an agreement that considers the proposed recommendations. ${ }^{94}$

Conversely, non-evaluative mediators cherish the idea that the parties in a dispute are best situated to solve their own conflict. ${ }^{95}$ The neutral acknowledges differences and commonalities between the parties, listening carefully for facts, interests, and feelings that can offer the basis to develop mutual understanding. ${ }^{96}$ No evaluation concerning the

the parties or their lawyers"); see Riskin L., Decisionmaking in Mediation: The New Old Grid and the New New Grid System, 79 Notre Dame L. Rev. 1 (2003), p. 22.

91 See, Levin, supra, p. 269.

92 See, Levin, supra, p. 269.

93 See, Levin, supra, p. 269.

94 See, Levin, supra, p. 269.

95 See, Levin, supra, p. 268.

96 See, Levin, supra, p. 268. 
merits of a case or its potential outcome is offered; an agreement, if reached, is solely based on the solutions proposed and shaped by the parties. ${ }^{97}$

As Riskin noted, the continuum described in his grid was interpreted by scholars as a dichotomy between non-evaluative and evaluative approaches; such dualistic reading of the role of the mediator contributed to a polarization both in literature and practice. ${ }^{98}$ However, some contemporary commentators argue that these two approaches are not running parallel to each other at the opposite side of the mediation spectrum, but can be blended together by mediators when appropriate during the course of the proceedings. ${ }^{99}$ As the discourse on mediation evolves, additional styles and models continue to originate.

97 See, Levin, supra, p. 268. Riskin clarified that the terms facilitative and evaluative were originally designed to highlight the mediators' impact on parties' self-determination. In Riskin's view, the term "evaluate" included "a certain set of predictive or judgmental or directive behaviors by the mediator that tend (or by which the mediator means) to direct (or influence or incline) the parties toward particular views of their problems, toward a particular outcome, or toward settlement ... such behaviors often or typically interfere with party self-determination. In contrast, the term 'facilitate' included a variety of actions by the mediator-not involving such influences-that tend ... to help or allow the parties to find their own way and make their own choices based on their own understandings;" see, Riskin L., Decisionmaking in Mediation: The New Old Grid and the New New Grid System, 79 Notre Dame L. Rev. 1 (2003), p. 18-19.

98 See, Riskin L., Decisionmaking in Mediation: The New Old Grid and the New New Grid System, 79 Notre Dame Law Review 1 (2003), footnote 44, p. 14. See, generally, Rubinson R., Of Grids and Gatekeepers: The Socioeconomics of Mediation, 17 Cardozo Journal of Conflict Resolution 837 (2016); Lande J., Toward More Sophisticated Mediation Theory, Journal of Dispute Resolution 321 (2000); Birke, R., Evaluation and Facilitation: Moving Past Either/Or, Journal of Dispute Resolution 309 (2000).

99 See, Stempel, J., Identifying Real Dichotomies Underlying the False Dichotomy: Twenty-First Century Mediation in an Eclectic Regime, Scholarly Works Paper 216 (2000), p. 376 (“... a mediator must operate under a legal regime that treats eclectic mediation as legitimate and that permits the mediator substantial discretion to do what he or she thinks best in each particular case."). For a similar point of view, see Yeo J., Contemporary Issues in Mediation, Volume 1, Chapter three: The Facilitative-Evaluative Divide: Have We Lost Sight of What's Important?, World Scientific (2016). 
In the following paragraphs, I analyse three different non-evaluative approaches to family and community mediation that were previously adopted in the context of clinical legal education: facilitative mediation, transformative mediation, and circle process. Then, based upon my analysis, I propose a model tailored to the cultural, legal, and educational needs of LUMSA and of the families the clinic hopes to serve. Finally, I lay out sources and materials for the proposed curriculum, including an original roleplay.

\section{Facilitative Mediation}

Facilitative mediation promotes a non-evaluative model based on active listening and question sequencing techniques that focus on recognition and acknowledgment of facts, interests, and feelings in a confidential setting. Issues that created conflict between the parties are approached comprehensively and impartially. The mediators' role is to empower the parties to self-determine the scope of their participation and reach a consensual agreement, if possible. ${ }^{100}$

Of particular interest and great practical effectiveness is the technique called "Question Funnel", which explains how to effectively use questions during the mediation

100 See, Riskin (1996) supra, p. 24 ("[t]he mediator who facilitates assumes that the parties are intelligent, able to work with their counterparts, and capable of understanding their situations better than the mediator and, perhaps, better than their lawyers. Accordingly, the parties can create better solutions than any the mediator might create. Thus, the facilitative mediator assumes that his principal mission is to clarify and to enhance communication between the parties in order to help them decide what to do."). 
process. This approach encourages mediators to start a session with simple open ended questions (for example, "what brought you here today?") to gather as much information as possible. Then, the inquiry should get progressively narrower ("tell me more about ..."), directing the information gathering process towards previous positive events, interactions and experiences mutually shared by the parties-this is a particularly significant step in the context of family mediation, where previous relationships play a key role and rapport is fundamental.

After each party has answered a common open ended question, a joint summary should always follow. At this stage, it might be useful to help the parties setting up an agenda and channel their conversation toward the most important issues to discuss. Mediators are encouraged to take advantage of previously gathered information to identify and acknowledge parties' underlying feelings and interests. Often times, active listening, reflections, and summaries would be enough to make the parties feel understood, transforming their original positional behavior into a more productive and flexible approach to conflict resolution. When this positive shift happens and the parties move towards a potential agreement, mediators might ask closed questions to reality check durability and viability of the solution proposed by the parties. 


\section{The Question "Funnel"}

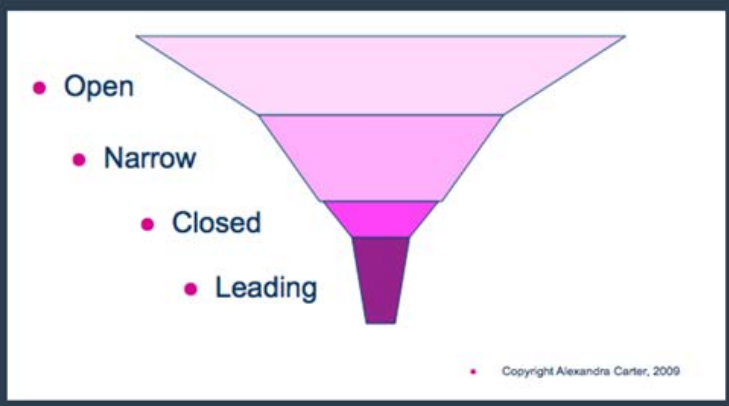

Professor Alexandra Carter, Columbia Law School Mediation Clinic Training Material

In 2009, the University of Virginia School of Law created a pilot family ADR clinic, which adopted a facilitative approach. ${ }^{101}$ Before mediating, students had the opportunity to meet with their supervisor to discuss their expectations and goals for the upcoming mediation; after the session, students wrote reflection papers analysing their conduct and performance in light of the practical lessons learned. This exercise fostered the students' ability to recognise their respective strength and weaknesses, and find ways to reinforce and improve their skills. ${ }^{102}$ The program also included training sessions, seminars and

101 See, Emery K., Assisting Indigent Families in Conflict: A Pro Bono Test Drive for a Family Alternative Dispute Resolution (ADR) Clinic, Journal of Law \& Policy, Vol. 34:239 (2010), p. 249.

102 See, Emery, supra, p. 250. 
class discussions organised in conjunction with the University's clinical psychology program, creating a very informative interdisciplinary learning opportunity. ${ }^{103}$

The combination of law and psychology forged strong interdisciplinary links that enhanced the quality of the service provided to the parties, especially in delicate situations such as educating clients on how to focus on the best interests of their children. ${ }^{104}$ In conclusion, this flexible and innovative framework created incentives for students to go out of their comfort zone, structuring particularly complex issues "in terms of real people ... rather [than] in terms of rules and principles," ${ }^{105}$ focusing on feelings and interests rather than facts and rules.

\section{Transformative Mediation}

The transformative mediation approach developed in the last two decades from the work of Professors Baruch-Bush and Folger. ${ }^{106}$ According to the transformative view, conflict develops from a crisis in human interactions caused by two feelings: (i) weakness, which should be replaced by strength, and (ii) self-absorption, which should be substituted by responsiveness. ${ }^{107}$ These feelings are a normal consequence of conflict and

\footnotetext{
103 See, Emery, supra, p. 250.

104 See, Emery, supra, p. 253.

105 See, Emery, supra, p. 253.

106 See, generally, Baruch-Bush R. and Folger J., The promise of mediation. Responding to conflict through empowerment and recognition, Jossey-Bass (1994); and Baruch-Bush R. and Folger J., The promise of mediation: The transformative approach to conflict, Jossey-Bass (2005).

107 See, Goodhart I. et al., Transformative Mediation: Assumptions and Practice, 11(2) Journal of Family Studies 317 (2005), p. 318.
} 
affect how people experience themselves and others. ${ }^{108}$ In the transformative process, the bridge from weakness to strength is empowerment, and the bridge from self-absorption to responsiveness is recognition. ${ }^{109}$ This path to transformation and regeneration of the parties' relationship gradually creates a virtuous circle that shifts "negative, destructive, alienating and demonizing interaction[s] to ... positive, constructive, connecting and humanising [ones,] even while conflict and disagreement are still continuing."110

\section{CHANGING CONFLICT INTERACTION}

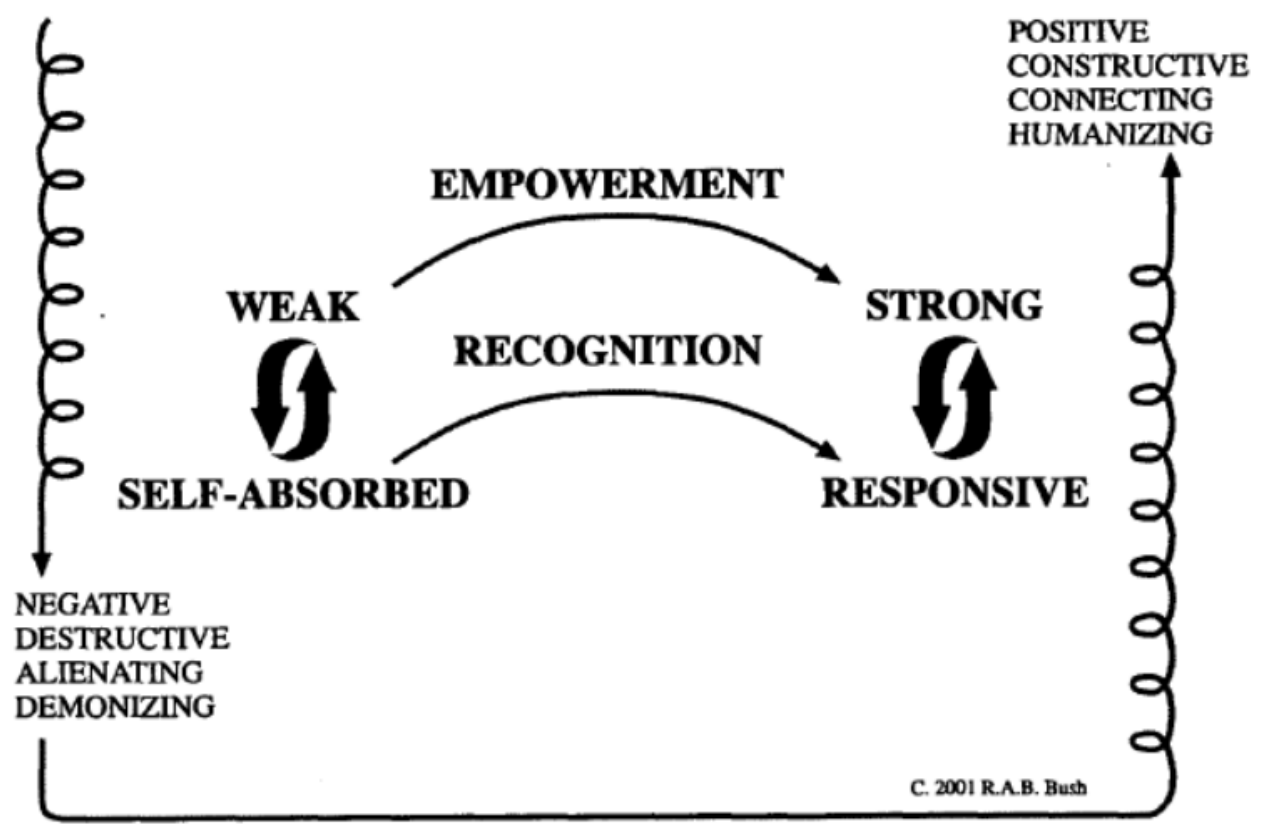

108 See, Baruch-Bush R. and Ganong Pope S., Changing the Quality of Conflict Interaction: The Principles and Practice of Transformative Mediation, 3 Pepp. Disp. Resol. L.J. 67 (2002-2003), p. 74.

$109 \quad$ See, Goodhart et al., supra, p. 319.

110 Baruch-Bush and Ganong Pope, supra, p. 82. 
Baruch-Bush R. and Ganong Pope S., Changing the Quality of Conflict Interaction: The Principles and Practice of Transformative Mediation, Fig. 2, p. 81

In order to create opportunities for empowerment and recognition mediators must know the language of conflict transformation, ${ }^{111}$ which includes:

- Close listening and observation of changes in the body language of the parties as different messages are conveyed; ${ }^{112}$

- Reflecting what the mediator hears back to the parties, using their own words when possible, and especially when the language is strong, loud, negative or strongly expressive. ${ }^{113}$ This technique's purpose is to give the parties an opportunity to "hear their own words in the same way as the other party has heard them, ... enabling them to see and feel what it is like to be 'on the receiving end,'"'114

- Summarising what has been said during the mediation, helping the parties making informed decisions about where they want the process to go. ${ }^{115} \mathrm{In}$ using this tool, mediators should remember that "[t]he summary is not an

111 See, Baruch-Bush and Ganong Pope, supra, p. 86-87.

112 See, Baruch-Bush and Ganong Pope, supra, p. 88.

113 See, Baruch-Bush and Ganong Pope, supra, p. 89.

114 Goodhart I., et al., supra, p. 320.

115 See, Baruch-Bush and Ganong Pope, supra, p. 89. 
educational monologue ... and has no agenda or direction built into it. It is a powerful tool for supporting empowerment and recognition when it highlights the differences between the parties, and the choices they face;" 116

- Regularly checking-in with the parties, preserving the voluntary nature of mediation and its self-determination purposes. Mediators can ask questions during the conversation to check their understanding of the parties' views; in particular, " $[\mathrm{w}]$ hen there is a fork in the road, it is helpful for the mediator to point it out and ask the parties which direction they want to take." ${ }^{117}$

Transformative mediators seek to support the family in the transition from destructive to constructive dialogue, focusing on self-determination and allowing the parties to be agents of their own change. ${ }^{118}$ The ultimate goal of transformative mediation is not to offer a third-party solution, but to accompany the parties into their journey from weakness and self-absorption to strength and responsiveness.

The transformative mediation model was implemented in 2008 by Hofstra Law School's mediation clinic to help families in Nassau County, New York. ${ }^{119}$ Students and social workers received a forty-hour training in transformative mediation, focused on

116 Baruch-Bush and Ganong Pope, supra, p. 89.

117 Baruch-Bush and Ganong Pope, supra, p. 90.

118 See, Baruch Bush R., et al., Supporting Family Strength: The Use Of Transformative Mediation In A Pins Mediation Clinic, 47(1) Family Court Review 148 (2009), p. 157.

119 See, Baruch Bush et al., supra, p. 158. 
working with parents and teens. Then, over an average period of three months, each family involved in the program periodically received mediation sessions devoted to enhancing their communication skills, creating a better understanding of their situation, and making informed and collaborative decisions about the appropriate course of action. ${ }^{120}$ In the first month, mediation sessions focused on increasing dialogue within the family, identifying the main areas of conflict, and eventually proposing solutions concerning day-to-day activities, like chores. ${ }^{121}$ During the second month, families were asked to engage in mediation to evaluate impact and feasibility of their agreements in the long term, discuss their progress, detect if any potential new issues emerged, and decide whether to stay in the program. ${ }^{122}$ The final month was focused on providing families with tools to approach conflict in a productive manner without external intervention, helping them to design tailored solutions to cope with future issues. ${ }^{123}$

During their experience in the clinic, students mediated real cases under the supervision of professors or certified mediators, adopting a co-mediation model and a transformative approach in which mediators (i) constantly reflected the parties verbal interactions, "capturing and uplifting their comments so that they can actually hear and listen to each other (and to themselves), as they express their views, feelings, and desires;"

120 See, Baruch Bush et al., supra, p. 158.

121 See, Baruch Bush et al., supra, p. 159.

122 See, Baruch Bush et al., supra, p. 159.

123 See, Baruch Bush et al., supra, p. 159. 
and (ii) regularly summarised the content shared by the parties, as their conversation unfolded. ${ }^{124}$ A social worker was also present at every meeting to guarantee the safety and feasibility of proposed agreements, preventing potential risks of foreseeable harm to minors. ${ }^{125}$ In contrast to the circle process (analysed below), usually only immediate family members were invited to partake in mediation, but relatives, therapists, community members and other interested parties were allowed to join all or some of the sessions on a case-by-case basis when the interests of the family and/or the complexity of the issues so required. ${ }^{126}$

According to the Hofstra Law School faculty members involved, this program was a success, and the transformative approach represented the best option since it provided a clear and coherent theory underlying the practice of mediation that students could easily and readily learn. ${ }^{127}$

\section{Peacemaking Circle}

The circle process is one of the most ancient forms of peaceful dispute resolution, which preceded the development of laws, courts, and judicial systems, emerging organically in almost all indigenous civilizations. ${ }^{128}$ In the African continent, circles are

\footnotetext{
$124 \quad$ Baruch Bush et al., supra, p. 159.

125 See, Baruch Bush et al., supra, p. 160.

126 See, Baruch Bush et al., supra, p. 161.

127 See, Baruch Bush et al., supra, p. 162.

128 See, Daicoff S., Families in Circle Process: Restorative Justice in Family Law, 53(3) Family Court Review 427 (2015), p. 431.
} 
Reviewed Article - Teaching and Learning in Clinic

often grounded in the concept of $u b u n t u$, a collaborative approach to reconciliation and restoration of harmony within a community. ${ }^{129}$ In general, these proceedings are informal, flexible, and anchored to the idea that peace is a communal matter that involves society at large. ${ }^{130}$ In Ethiopia, Afar communities use a process called maro, in which elders, disputants, witnesses and observers sit in a circle under a tree to resolve conflict when disputes arise. ${ }^{131}$ In New Zealand, the Maori population used to practice the whanau conference, which gathered extended families and clans of victims and offenders. ${ }^{132}$ In Native American culture, circles have traditionally been used to settle disputes and make shared decisions concerning the community. ${ }^{133}$ In this process, one or more individuals facilitate the conversation while a symbolic object is passed around in a circle, and the

129 Daicoff, supra, p. 431.

130 See, Boniface E., African Style Mediation and Western-Style Divorce and Family Mediation: Reflections for the South African Context, 15(5) Potchefstroom Electronic Law Journal 378 (2012), p. 383-384. For a comprehensive explanation of the meaning of ubuntu, see McAllister, P., Ubuntu - Beyond Belief in Southern Africa, 6(1) Sites: New Series 1 (2009) and Murithi T., An African Perspective on Peace Education: Ubuntu Lessons in Reconciliation, 55(2-3) International Review of Education 221 (2009).

131 See, Gebre-Egziabher K. A., Dispute resolution mechanisms among the Afar People of Ethiopia and their contribution to the Development Process, 10(3) The Journal for Transdisciplinary Research in Southern Africa 152 (2014), p. 156-157. See, also, Morris D., Dispute resolution - an archaeological perspective with case studies from the South African Stone Age and San ethnography, 10(4) The Journal for Transdisciplinary Research in Southern Africa 120 (2014); this article offers an interesting archeological perspective on the development of peaceful dispute resolution practices in the South Africa.

132 See, Zernova M., Restorative Justice: Ideals and Realities, International and Comparative Criminal Justice Series, Routlege, 2016, p. 10.

133 See, Bradford W., Reclaiming Indigenous Legal Autonomy on the Path to Peaceful Coexistence: The Theory, Practice, and Limitations of Tribal Peacemaking in Indian Dispute Resolution, 76 North Dakota Law Review 551 (2000) p. 565 (“... disputes within the tribe were typically resolved ... with the aid of respected elder members of the tribe who would guide the parties to a compromise restorative of the community."). In the traditional Navajo peacemaking process (called hozhooji naat'aani) members of the tribe sit in a circle and discuss their issues at length. The system is horizontal, which means that everyone is an equal, every opinion has the same authority and agreements are reached via consensus; see, Yazzie R., "Hozho Nahasdlii" -- We Are Now in Good Relations: Navajo Restorative Justice, 9 St. Thomas Law Review 117 (1996), p 122. 
person who holds it has an opportunity to speak without interruption; members are usually gathered in plain view of one another and "the power of the talking circle group resides within the group, not with an individual member." 134

The above mentioned methods, despite obvious differences from one another, are rooted on the same core principles: inclusion, participation, and accountability. The fact that an entire community can be present when the conflict is approached, have a voice in the solutions, support families in keeping agreements, and promote post-dispute relationships generates mutual respect, equality, dignity, tolerance, collaboration and a sense of interconnectedness that make the circle process particularly suitable for family law. ${ }^{135}$

134 Jennings L. et al., Using the Native American Talking Circle: Experiential learning on ethnic and cultural diversity of Southern California, 25(1) Groupwork 58 (2015), p. 59. For an extensive discussion of how certain debilitating addictions that threaten families and communities can be cured via therapeutic jurisprudence and wellness courts, see Flies-Away J.T. and Garrow C., Healing To Wellness Courts: Therapeutic Jurisprudence, 2013 Michigan State Law Review 403 (2014).

$135 \quad$ See, Daicoff, supra, p. 430. 


\section{The General Circle Format}
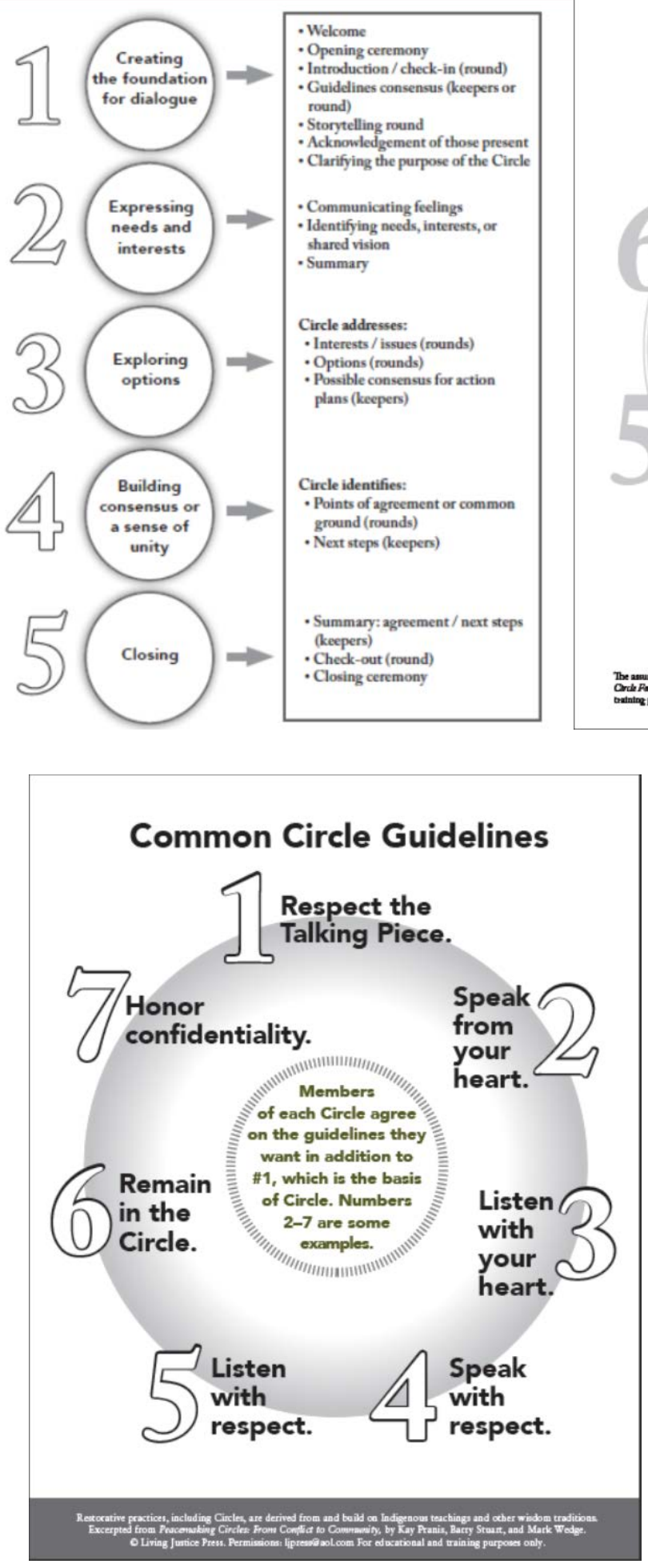

\section{Seven Core Assumptions}

What We Believe to Be True

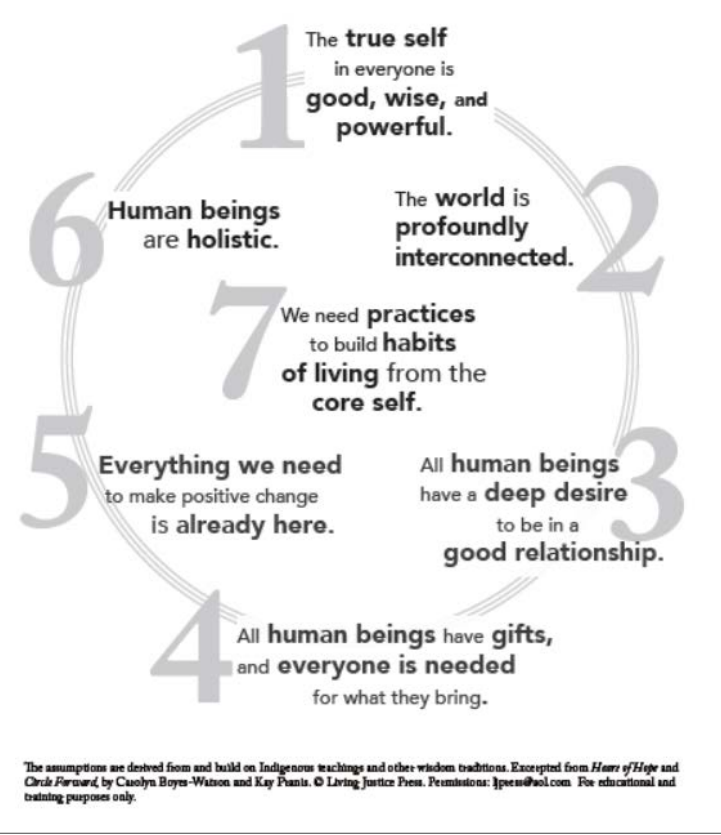

Living Justice Press; see,

http://www.livingjusticepress.org/index.asp?Type=B_BASIC\&SEC $=\{$ B158346E2E21-48C6-94DC-A71301BE3D0F\}. 
This framework was tested in 2008, when the Cook County Parentage and Child Support Court in Illinois partnered with DePaul College of Law to create a free program devoted to the promotion of peacemaking circles within families in disagreement. Feedback from the families involved in the program showed that the circle experience had a positive and enduring impact on communication in conflict situations. ${ }^{136}$ In particular, "[t]he restorative process helped to create ... better dialogue ... encourag[ing] accountability and responsibility of the parents to their children and for their children." 137

After having considered the main features of facilitative, transformative and peacemaking approaches and having described notable examples of their implementation in family mediation programs across the United States, the following section will analyse how these models can be tailored to the family mediation services that the LUMSA clinic will offer. This inquiry will consider how specific cultural beliefs and societal norms that inform Italian catholic communities play a role in determining the best approach to conflict resolution. In addition, the following section will identify role and mission of the clinic within the law school curriculum and discuss important guidelines to consider in order to provide prospective students with a meaningful and productive learning experience.

\footnotetext{
136 See, Daicoff, supra, p. 434.
}

$137 \quad$ Daicoff, supra, p. 434. 


\section{Tailored model for LUMSA Family Mediation Clinic}

The first step in shaping the LUMSA model is to articulate the role and mission of the clinic within the law school curriculum.

Professor Wilson indicated the five components that define his "ideal model of clinical legal education." ${ }^{138}$ Wilson's model requires that: (1) academic credit is granted to students for participation in the clinic; (2) actual clients with real legal problems are represented within a framework permitted by local statute, bar or court rules permitting limited student practice, advice or other legal services; (3) clients served by the program are legally indigent and/or come from traditionally disadvantaged, marginal or otherwise underserved communities; (4) students are closely supervised by attorneys and/or professors who share the pedagogical objectives of clinical legal education; (5) case-work by students is preceded or accompanied by a law school course on the skills, ethics and values of practice. ${ }^{139}$

138 Wilson (2009), supra, p. 829. Originally, in Wilson R., Training for Justice: The Global Reach of Clinical Legal Education, 22 Penn State International Law Review 421 (2004), the author indicated six components, but later decided to reduce the number to five because he combined two components into one.

139 See, Wilson (2009), supra, p. 829-830. Those components are very similar to the ones originally adopted by Professor Liebman and still used by the Columbia Law School Mediation Clinic; see paragraph B.II, above. 
LUMSA Family Mediation Clinic should include all the components listed by Professor Wilson, in order to provide a structured, meaningful and effective learning experience for its participants. In particular, the clinic should:

- award academic credit for students that successfully partake in clinical activities;

- comply with the provisions listed in section B.I and be listed in the Ministry of Justice's register;

- work with low income and disadvantaged families and communities;

- offer academic supervision by faculty members who share the pedagogical objectives of clinical legal education; and

- include basic skills trainings, interactive classes, role-play activities, lectures and group discussions concerning mediation theory, practice, ethics and policy issues.

Further, the different mediation models analyzed in the foregoing sections B.IIB.IV provide interesting options for the proposed Italian mediation clinic. Peacemaking circles have the perk of involving entire communities in conversations devoted to solving family conflicts, offering a variety of views concerning issues and solutions. Moreover, sincere and productive help from community members could generate great support to the parties in maintaining their commitments. However, this model does not seem to fit 
appropriately into Italian culture, which values privacy as a fundamental principle when it comes to family conflicts. One of the most widespread and ancient Italian saying goes i panni sporchi si lavano in casa (dirty clothes are washed inside the house), which means that private unflattering conflicts that rise within the family shall be resolved by family members, without external intervention. Moreover, this view is strongly followed by Catholic families like the ones that LUMSA Mediation Clinic would mainly serve. For this very simple yet decisive cultural reason, the circle process does not seem to be a feasible option; most families would probably feel embarrassed and/or reluctant to discuss family matters before other members of their community, diminishing the effectiveness of this method.

The above mentioned privacy concerns still play a role in transformative and facilitative approaches; however, mediators have more leeway to manage this cultural privacy tension. People who partake in mediation can be limited according to the needs of each specific case, ranging from immediate family members to relatives, therapists, and social workers. In addition, confidentiality can be assured via a confidentiality agreement. Transformative and facilitative mediation have many other positive features in common; they wish to transform conflict into a productive dialogue, relying heavily on the use of (i) active listening skills, (ii) various techniques to filter, reframe, and reflect the words said by the parties, and (iii) regular summaries of the information shared by the parties during the mediation. The main substantial difference between these two 
approaches lays in how mediators interpret their role and goals. The facilitative style focuses on resolving issues emerged during the mediation; the transformative approach goes further; it wishes to tackle family dynamics that cause conflict, improving the parties' relationship as a whole. ${ }^{140}$ In practice, however, these distinctions tend to fade; each mediator can - to a certain extent - tailor her style to specific cases' needs, assessing the complexity and gravity of the disagreement and determining the level of resolution required.

For all these reasons and in light of Professor Liebman's suggestions (see paragraph B.II), LUMSA family mediation clinic should adopt facilitative mediation, with transformative tendencies when family conflicts seem rooted, serious, and repetitive to require a much deeper inquiry into reasons and dynamics that create disagreement within the family and threaten the underlying relationships. The learning experience should start with an intensive course focused on teaching students foundational conflict resolution tools (active listening, reflecting, summarising, and checking in), illustrated in paragraph C.III, and the "The Question Funnel" technique, analysed in paragraph C.II. The clinic should implement a co-mediation structure. Professors should pair students in light of their effectiveness as a team during the role-play activities performed during the intensive course. The co-mediation scheme should promote collaboration among clinical 
students and make it easier for beginners to approach real-life disputes without being overwhelmed. After the initial intensive training, students should start mediating real cases under the supervision of faculty members and/or experienced mediators, having interactive classes, lectures and discussions and write short weekly reflection papers (from 3 to 5 pages) based on the analysis of the readings assigned and of the practice of mediation.

The following section will complement the foregoing analysis with seminal resources and materials that will constitute the backbone of the LUMSA clinic's curriculum. In addition, I will include an original role-play that touches upon family disputes with elder care.

\section{The Curriculum: Resources, Materials, and Role-Play}

My proposed resources for LUMSA family mediation clinic's curriculum are mainly based on the materials assigned by the Columbia Law School Mediation Clinic. In particular, I would recommend adopting the book "Difficult Conversations: How to Discuss What Matters Most" by Douglas Stone, Bruce Patton and Sheila Heen; chapters 4, 5, and 6 of "The Practice of Mediation" by Douglas Frenkel and James Stark; and some exercises included in "Conquer Your Critical Inner Voice: A Revolutionary Program to Counter Negative Thoughts and Live Free from Imagined Limitations" by Robert Firestone, Lisa Firestone, Joyce Catlett, and Pat Love. Unfortunately, these materials have 
not yet been translated into Italian. However, this task can be performed by students under the supervision of LUMSA professors, with permission from the authors, when necessary.

Moreover, following the University of Virginia School of Law's footsteps (see paragraph C.II), it would be incredibly useful to supplement this material with specific content provided by experts in child psychology and sociologists specialising in family conflict. This interplay between law and psychology would be beneficial both to students and families involved in the clinical program to reach agreements that are mindful of the delicate issues faced in family mediation.

Finally, I include a sample role-play that concerns elderly care and family conflict. The role-play is called "The Decision" and requires three participants and two comediators.

\section{THE DECISION ROLE-PLAY}

General information for the mediators and the parties

Veronica is a 77 year-old widow. Her husband died when she was 40 years-old, causing her great emotional suffering. Five years after his death, while visiting her sister in a summer location far from her town, Veronica met Vincenzo, a widower. They started 
a relationship, and eventually moved in together in Vincenzo's house, in a city far away from Veronica's family.

The relationship by all measures was a success; they have lived happily together for many years. However, two years ago Vincenzo (then, 82 years old) started losing his memory, and was diagnosed with Alzheimer and dementia. Unfortunately, as result of the disease, Vincenzo's memory continued to deteriorate, but Veronica stood by his side despite all the difficulties. Recently, Vincenzo's disease has diminished his memory and cognitive abilities to the point that he often confuses Veronica for his deceased wife and has trouble recognising his sons.

About two months ago, Vincenzo fell from a chair, breaking his thighbone, and was hospitalised. Around the same time, Veronica started suffering from a severe and persistent stomach ache. Further medical examinations showed the presence of a mass in her stomach, which required further testing. It was clear that Vincenzo's sons, already busy assisting Vincenzo at the hospital, could offer Veronica little support with her newly discovered medical condition. They promptly informed Veronica's three daughters Anna, Lisa, and Iolanda (today's parties) of the situation. Veronica's daughters decided to take some time off from work to go visit their mother. Realising that her condition could be serious and considering Vincenzo's sons' limited availability, they decided to temporarily take Veronica back to their hometown with them. 
Since then, the newly performed tests on Veronica's stomach showed that the mass was a very aggressive cancer, and that Veronica's chances of surviving are close to none. The doctors consulted with Anna, Lisa, and Iolanda to assess how to proceed. The daughters strongly disagreed on how, if at all, to convey the difficult and sensitive information to Veronica, and decided to try mediation.

Unaware of the severity of her medical condition, Veronica planned a trip to visit her beloved Vincenzo. This trip could be the last opportunity for Veronica to see Vincenzo before her health makes it impossible. Thus, time is of the essence to decide whether and to what extent to inform Veronica about her cancer.

\section{THE DECISION ROLE-PLAY}

\section{Confidential information for Anna}

Your mother never shared with you or your sisters her wishes in case something like this happened.

You are extremely worried about your mother and blame Vincenzo's sons for not having paid attention to the signals of Veronica's illness. If they were more attentive, they could have realized that something was wrong with her, and act when her chances of surviving were better. 
Also, you know your mother better than anybody else. Being the oldest daughter, you comforted her when your father passed away, creating a very strong bond. You also developed a very deep relationship with your sisters, and became their mentor when your mother left.

You think that by telling her the truth about her disease she would start feeling extremely sad, to the point that she might even refuse medication and blow her already minimal chances of surviving. However, you know how much she loves Vincenzo, and do not want to prevent her from going to see him for what might be the last time. You are devastated by the idea that she might not know that the upcoming visit to Vincenzo could represent the last time she sees him. Despite that, you still think that not telling her of the whole truth is preferable since it would give her hope.

Even though you have very specific ideas on what is best for your mother, ultimately you want whatever decision that is made to be one that you and your sisters can all agree to and feel comfortable with despite your different opinions.

\section{THE DECISION ROLE-PLAY}

\section{Confidential information for Lisa}

Growing up, you never forgave your mother for prioritizing her relationship with Vincenzo over the one with you. In fact, your relationship has never been the same again 
since she moved in with Vincenzo, but you still deeply care about her, and the news about her cancer devastated you. You never met Vincenzo or his family before the occurrence of these sad events.

You want to make sure to make the best decision for Veronica, but unfortunately your mother never shared with you or your sisters her wishes in case something like this happened.

You are unsure about what to do, and feel extremely lost. You want to hear what both of your sisters have to say before making up your mind. Ultimately you want whatever decision that is made to be one that you and your sisters can all agree to and feel comfortable with despite your different opinions.

\section{THE DECISION ROLE-PLAY}

\section{Confidential information for Iolanda}

You are the youngest sister in the family. At the beginning you had a hard time accepting your mother's decision to leave, but with time you came to terms with it. You also had many opportunities to meet with Vincenzo and his sons, and really like them and the way they treat your mother.

Despite the fact that your mother never shared with you or your sisters her wishes in case something like this happened, you believe she would like to know about her 
condition. You also believe that her knowledge would definitely affect her decision to see and interact with Vincenzo. You believe she deserves to know the truth and make an informed decision about her future, including how to approach the upcoming meeting with Vincenzo.

Even though you have very specific ideas on what is best for your mother, ultimately you want whatever decision that is made to be one that you and your sisters can all agree to and feel comfortable with despite your different opinions.

\section{Conclusions}

First, the organisational structure of LUMSA Mediation Clinic should comply with all the provisions analysed in section B.I above and seek admission to the register maintained by the Ministry of Justice. This is a fundamental step to ensure that all the activities of the clinic are carried on in compliance with the law.

Then, given the cultural background of Italy and most of the families that will be serviced by the clinic, I believe that the best mediation model to implement at LUMSA is the facilitative approach, with transformative tendencies as needed, as described in section C.V. Furthermore, the legal clinic should adopt a co-mediation structure, and assign students weekly reflection papers. 
While many resources already exist in English, the mediation clinic may find it useful and worthwhile to look into what needs to be done to translate the seminal texts included in section C.VI. To expand the available educational material, the clinic should also design and rely on role-plays that are similar to the disputes that students may face in the field and reflect cultural knowledge of the community, like the sample role-play included in section C.VI. In addition, the clinic should consider having an interdisciplinary approach that might better address all the complex needs that arise in family disputes.

In relation to funding, the clinic should rely on the direct investment of LUMSA and indirect patronage, especially in the form of donations. Moreover, despite the foreseeable difficulties illustrated in the preceding section A.II, the clinic should apply for European grants. In the future, once LUMSA family mediation clinic becomes a structured and well-established reality, it may be advisable to create an advance clinic model capable of furthering students' learning experiences and generating revenues, for example in the form of trainings that assign professional and ethics credits to Italian qualified lawyers and practitioners. 